\title{
Molecular Imaging of Angiogenesis in Oncology: Current Preclinical and Clinical Status
}

\author{
Alexandru Florea ${ }^{1,2,3}(\mathbb{D})$, Felix M. Mottaghy $1,2,3,4, *(\mathbb{D})$ and Matthias Bauwens $1,2,4$ \\ 1 Department of Nuclear Medicine, University Hospital RWTH Aachen, 52074 Aachen, Germany; \\ aflorea@ukaachen.de (A.F.); matthias.bauwens@mumc.nl (M.B.) \\ 2 Department of Radiology and Nuclear Medicine, Maastricht University Medical Center, 6229HX Maastricht, \\ The Netherlands \\ 3 School for Cardiovascular Diseases (CARIM), Maastricht University, 6229HX Maastricht, The Netherlands \\ 4 School of Nutrition and Translational Research in Metabolism (NUTRIM), Maastricht University, \\ 6229HX Maastricht, The Netherlands \\ * Correspondence: fmottaghy@ukaachen.de; Tel.: +49-241-80-88741
}

Citation: Florea, A.; Mottaghy, F.M.; Bauwens, M. Molecular Imaging of Angiogenesis in Oncology: Current Preclinical and Clinical Status. Int. J. Mol. Sci. 2021, 22, 5544.

https://doi.org/10.3390/ijms22115544

Academic Editor: Christophe V. van de Wiele

Received: 21 April 2021

Accepted: 20 May 2021

Published: 24 May 2021

Publisher's Note: MDPI stays neutral with regard to jurisdictional claims in published maps and institutional affiliations.

Copyright: (c) 2021 by the authors. Licensee MDPI, Basel, Switzerland. This article is an open access article distributed under the terms and conditions of the Creative Commons Attribution (CC BY) license (https:// creativecommons.org/licenses/by/ $4.0 /)$.

\begin{abstract}
Angiogenesis is an active process, regulating new vessel growth, and is crucial for the survival and growth of tumours next to other complex factors in the tumour microenvironment. We present possible molecular imaging approaches for tumour vascularisation and vitality, focusing on radiopharmaceuticals (tracers). Molecular imaging in general has become an integrated part of cancer therapy, by bringing relevant insights on tumour angiogenic status. After a structured PubMed search, the resulting publication list was screened for oncology related publications in animals and humans, disregarding any cardiovascular findings. The tracers identified can be subdivided into direct targeting of angiogenesis (i.e., vascular endothelial growth factor, laminin, and fibronectin) and indirect targeting (i.e., glucose metabolism, hypoxia, and matrix metallo-proteases, PSMA). Presenting pre-clinical and clinical data of most tracers proposed in the literature, the indirect targeting agents are not 1:1 correlated with angiogenesis factors but do have a strong prognostic power in a clinical setting, while direct targeting agents show most potential and specificity for assessing tumour vascularisation and vitality. Within the direct agents, the combination of multiple targeting tracers into one agent (multimers) seems most promising. This review demonstrates the present clinical applicability of indirect agents, but also the need for more extensive research in the field of direct targeting of angiogenesis in oncology. Although there is currently no direct tracer that can be singled out, the RGD tracer family seems to show the highest potential therefore we expect one of them to enter the clinical routine.
\end{abstract}

Keywords: oncology; angiogenesis; PET; SPECT; VEGF; RGD; NGR; fibronectin

\section{Introduction}

Angiogenesis is an active process, which regulates the growth of new blood vessels from a pre-existing vascular bed and is crucial for any regenerative mechanisms and for the survival and growth of tumours. Under physiological conditions a fine-tuned regulation of pro- and anti-angiogenic factors expands the surrounding vascular network in the target tissue. However, in the case of solid cancers, there is a pathological misbalance in the favour of the pro-angiogenetic factors, which results in abnormal, leaky, new capillary formation, required for its rapid growth and metastasis [1]. Beyond its effects on tumour expansion, these immature capillaries facilitate tumour metastasis by providing an efficient route for the tumour cells to exit the primary site and enter the blood stream [2]. Therefore, pro-angiogenetic factors, including their respective receptors, are attractive targets in the molecular imaging of tumour vascularisation and vitality assessment.

Concentration gradient via diffusion may achieve a steady nutrient supply and waste product elimination only in tissues smaller than $2 \mathrm{~mm}$ in diameter. Henceforth, any tumour 
larger than this requires vascularisation for its subsequent growth. This is an important aspect, which is frequently overlooked, as both chemotherapy and imaging tracers that directly target the process of angiogenesis have a limited effect (if any) on primary tumours and metastases smaller than $2 \mathrm{~mm}$. Thus, the detection capabilities of imaging probes targeting angiogenesis are restricted both by the spatial resolution of the scanner and by the tumour volume. Nonetheless, as most solid tumours are prone to acquire resistance to anti-angiogenic therapies [3,4], there is an unmet need for non-invasive targeted imaging of tumour vascularisation and vitality.

Computed tomography (CT) and magnetic resonance imaging (MRI) are in principle not ideal for assessing tumour angiogenesis. These techniques mainly evaluate parameters such as changes in tumour volume, morphology, or even tumour blood flow/blood volume and vascular permeability, but they cannot quantify changes in the tumour vasculature. However, there are significant advances being made, especially with MRI, that allow imaging of angiogenesis-correlated parameters. This is beyond the scope of the current review, but interesting applications may be found in the following reviews [5-7].

Molecular imaging, either via positron-emitting isotopes for imaging with PET or via single photon emitting isotopes for imaging with SPECT, makes use of radioactively labelled tracers that bind to specific targets. The technique of molecular imaging is significantly more sensitive compared to CT and MRI, allowing for the visualisation and even quantification of sub-nanomolar concentrations of targets. Both PET and SPECT imaging techniques rely on small amounts of "tracers", which bind a specific molecular target. Both modalities comes with a long list of tracer parameters that need to be met, including good target to background ratio, fast clearance (preferably renal), suitable biodistribution, no toxicity, and high specificity for the specific target. Therefore, the field of molecular imaging is ever developing with improvements in the tracer, either via incremental improvements within a given class of compounds; or via "new" tracers that are used for targets that previously could not be detected.

The possible molecular mechanisms to combat angiogenesis in oncology have been previously described in many papers [1,4,8-10]. The scope of this review is to present the possible imaging options of tumour vascularisation and vitality via non-invasive molecular imaging, including potential PET and SPECT tracers to be implemented in the clinic.

The key question is to identify a suitable target for the PET and SPECT tracers. In adult tissues, under physiological conditions, there is a balance between the pro-and anti-angiogenic factors [11]. In situ tumours are usually separated from the vascularised peri-tumoural tissues by a basal membrane and blood vessels are rarely present in these lesions [12]. However, in the ever increasing hypoxic conditions created when reaching $2 \mathrm{~mm}$, tumour cells start secreting paracrine factors, thus recruiting surrounding stromal fibroblasts, which will differentiate into tumour associated fibroblasts (i.e., CAFs) [13]. The CAFs in turn lyse local extracellular matrix via matrix metallo-proteases (MMPs), secrete inflammatory factors (e.g., interleukins) and start laying down the scaffolding for tissue repair and angiogenesis, by secreting fibronectin, laminin, and hyaluronate [3]. The MMPmediated degradation of a peri-tumoural post-capillary venule facilitates the migration of endothelial cells and pericytes toward the pro-angiogenic stimulus created by the tumour cells $[14,15]$. Thus, the sprouting of new blood vessels is directed by the concentration gradient of pro-angiogenic factors, reaching the tumour [9].

Angiogenesis is directed towards the hypoxic tissue mainly by integrins, which promote endothelial cell migration and survival and pro-angiogenic macrophage trafficking to tumours [16]. Many tumours over-secrete vascular endothelial growth factor (VEGF), a highly potent pro-angiogenic factor, which in combination with the permeable micro-environment created by CAFs, serve as the perfect background for extensive vessel formation [17]. This excess of pro-angiogenic factors left unchecked by the lack of anti-angiogenic ones leads to abnormal, leaky vessel formation, which is a hallmark of malignant angiogenesis [17]. This results in a suboptimal blood flow, leading to a maintained state of hypoxia and further VEGF production in a vicious cycle. Additionally, the 
abnormal vessel formation is an ideal entry point of tumour cells into the circulation by providing an increased density of immature, leaky blood vessels that have little basement membrane and fewer intercellular junctional complexes than normal mature vessels [18].

\section{Molecular Targets of Tumour Angiogenesis}

As angiogenesis is a multi-factorial process, there are a multitude of potential targets for molecular imaging. These targets can be subdivided into direct targets (specific receptors on or near the cell that are directly related to angiogenesis) and indirect targets (glucose metabolism, hypoxia-which are only indirectly correlated with angiogenesis) (Table 1, Figure 1).

Table 1. Classification of the most promising tracers for angiogenesis imaging.

\begin{tabular}{|c|c|c|c|c|}
\hline Imaging Method & Target & Tracer Name & Modality & Stage \\
\hline \multirow{6}{*}{$\begin{array}{l}\text { Indirect targeting } \\
\text { of angiogenesis }\end{array}$} & $\begin{array}{l}\text { Glucose } \\
\text { metabolism }\end{array}$ & {$\left[{ }^{18} \mathrm{~F}\right]-\mathrm{FDG}$} & PET & accepted for clinical use \\
\hline & \multirow{3}{*}{ Hypoxia } & {$\left[{ }^{18} \mathrm{~F}\right]-\mathrm{HX} 4$} & PET & clinical trial [19] \\
\hline & & {$\left[{ }^{18} \mathrm{~F}\right]-\mathrm{FMISO}$} & PET & clinical trial [20] \\
\hline & & {$\left[{ }^{18} \mathrm{~F}\right]-\mathrm{FAZA}$} & PET & clinical trial [21], [22] \\
\hline & \multirow[t]{2}{*}{ MMPs } & {$\left[{ }^{18} \mathrm{~F}\right]-\mathrm{SAV} 03$} & PET & $\begin{array}{c}\text { in vivo preclinical stage } \\
{[23]}\end{array}$ \\
\hline & & {$\left[{ }^{68} \mathrm{Ga}\right]-N O T A-C 6$} & PET & $\begin{array}{c}\text { in vivo preclinical stage } \\
{[24]}\end{array}$ \\
\hline \multirow{14}{*}{$\begin{array}{l}\text { Direct targeting } \\
\text { of angiogenesis }\end{array}$} & \multirow{5}{*}{ VEGF } & {$\left[{ }^{123} \mathrm{I}\right]-\mathrm{VEGF} 165$} & SPECT & clinical trial [25] \\
\hline & & {$\left[{ }^{64} \mathrm{Cu}\right]$-DOTA-scVEGF } & PET & $\begin{array}{c}\text { in vivo preclinical stage } \\
{[26]}\end{array}$ \\
\hline & & $\begin{array}{c}\text { [99m Tc]-HYNIC- } \\
\text { scVEGF }\end{array}$ & SPECT & $\begin{array}{c}\text { in vivo preclinical stage } \\
\text { [27] }\end{array}$ \\
\hline & & {$\left[{ }^{89} \mathrm{Zr}\right]$-Bevacizumab } & PET & $\begin{array}{c}\text { in vivo preclinical stage } \\
{[28]}\end{array}$ \\
\hline & & {$\left[{ }^{111} \mathrm{In}\right]$-Bevacizumab } & SPECT & clinical trial [29] \\
\hline & \multirow{9}{*}{ Integrins } & $\begin{array}{c}99 \mathrm{~m} \text { Tc-labelled } \\
\text { anti-ED-B fibronectin } \\
\text { antibody }\end{array}$ & SPECT & $\begin{array}{c}\text { in vivo preclinical stage } \\
{[30]}\end{array}$ \\
\hline & & $\begin{array}{c}{ }^{123} \text { I-labelled anti-ED-B } \\
\text { fibronectin } \\
\text { antibody }\end{array}$ & SPECT & $\begin{array}{c}\text { in vivo preclinical stage } \\
{[31]}\end{array}$ \\
\hline & & $\begin{array}{l}{ }^{124} \text { I-labelled anti-ED-B } \\
\text { fibronectin } \\
\text { antibody }\end{array}$ & SPECT & $\begin{array}{c}\text { in vivo preclinical stage } \\
{[32]}\end{array}$ \\
\hline & & $\begin{array}{c}{ }^{76} \mathrm{Br} \text {-labelled anti-ED-B } \\
\text { fibronectin } \\
\text { antibody }\end{array}$ & PET & $\begin{array}{c}\text { in vivo preclinical stage } \\
{[33]}\end{array}$ \\
\hline & & {$\left[{ }^{123} \mathrm{I}\right]-\mathrm{L} 19(\mathrm{scFv})$} & SPECT & clinical trial [31] \\
\hline & & {$\left[{ }^{18} \mathrm{~F}\right]-$ Galacto-RGD } & PET & clinical trial [34] \\
\hline & & {$\left[{ }^{18} \mathrm{~F}\right]$-Fluciclatide } & PET & clinical trial [35] \\
\hline & & {$\left[{ }^{18} \mathrm{~F}\right]-\mathrm{RGD}-\mathrm{K} 5$} & PET & clinical trial [36] \\
\hline & & {$\left[{ }^{18} \mathrm{~F}\right]-\mathrm{FB}-\mathrm{RGD}$} & PET & $\begin{array}{c}\text { in vivo preclinical stage } \\
{[37]}\end{array}$ \\
\hline
\end{tabular}


Table 1. Cont.

\begin{tabular}{|c|c|c|c|c|}
\hline Imaging Method & Target & Tracer Name & Modality & Stage \\
\hline & & {$\left[{ }^{18} \mathrm{~F}\right]-\mathrm{PEG}-\mathrm{RGD} 2$} & PET & $\begin{array}{c}\text { in vivo preclinical stage } \\
{[37]}\end{array}$ \\
\hline & & $\begin{array}{c}{\left[{ }^{68} \mathrm{Ga}\right]} \\
\text { Ga-NODAGA-RGD }\end{array}$ & PET & clinical trial [38] \\
\hline & \multirow{3}{*}{ NGR } & ${ }^{99 m}$ Tc-labelled NGR & SPECT & $\begin{array}{c}\text { in vivo preclinical stage } \\
{[39]}\end{array}$ \\
\hline & & {$\left[{ }^{68} \mathrm{Ga}\right]-\mathrm{NOTA-c}(\mathrm{NGR})$} & PET & $\begin{array}{c}\text { in vivo preclinical stage } \\
{[40]}\end{array}$ \\
\hline & & ${ }^{64} \mathrm{Cu}$-labelled NGR & PET & in vivo preclinical stage \\
\hline
\end{tabular}

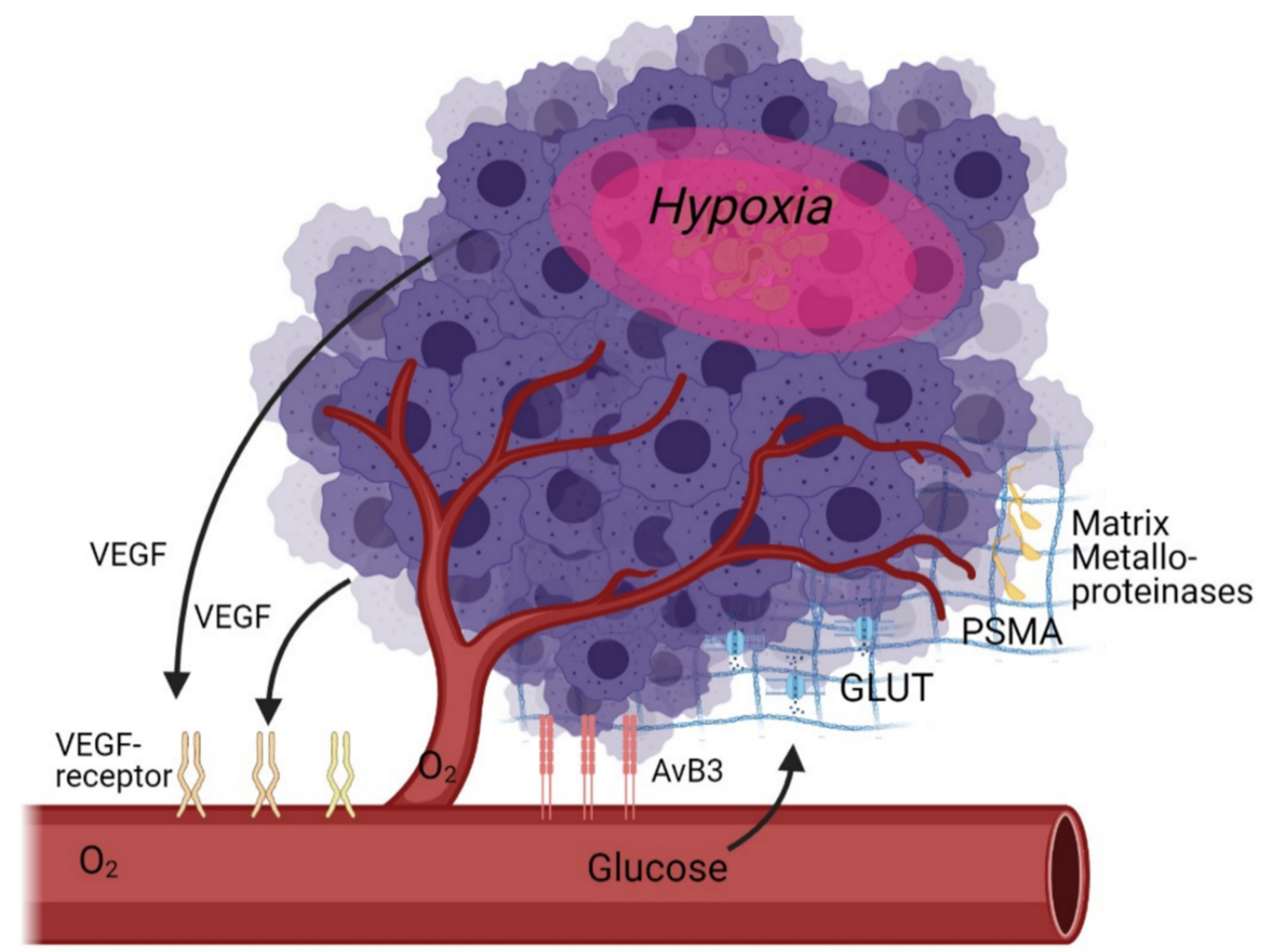

Figure 1. Schematic overview of angiogenesis targets in the tumour microenvironment as discussed in this review.

The discovery of VEGF has revolutionised the understanding of vasculogenesis and angiogenesis during embryogenesis and physiological homeostasis. It is the key mediator of angiogenesis and binds two VEGF receptors (VEGF receptor-1 and VEGF receptor-2), which are expressed on vascular endothelial cells $[8,42]$. It is up regulated by oncogene expression, a variety of growth factors and hypoxia. It is important to note that tumour vasculature formed in answer to VEGF influence is structurally and functionally abnormal: blood vessels are not organised into venules, arterioles, and capillaries, they are leaky and haemorrhagic.

Another key target for angiogenesis is integrins. The adhesive interaction of vascular endothelial cells is crucial in angiogenesis, with several adhesion molecules, including members of the integrin, cadherin, selectin, and immunoglobulin families as key effectors [43]. Integrins represent a family of cell-adhesion molecules crucial to cell-to-extracellular matrix and cell-to-cell interactions. Integrins are heterodimeric transmembrane glycoproteins composed of two non-covalently associated $\alpha$ and $\beta$ subunits, the specific combination of 
these units determines signalling properties as well as binding affinity for ligands (and therefore tracers). Especially important are the $\alpha_{\mathrm{v}}$ integrins, which are overexpressed on the surface of endothelial cells during angiogenesis. Different types of integrins can also imply different metastatic progresses: Hoshino et al. report that a high content of exosomal integrin $\alpha_{v} \beta_{5}$ was associated with liver metastasis, whereas exosomal integrins $\alpha_{6} \beta_{4}$ and $\alpha_{6} \beta_{1}$ correlates with lung metastasis [44]. $\alpha_{v} \beta_{3}$ integrin is one of the most studied integrins as it represents a highly specific biomarker to distinguish new from mature capillaries, allowing vascular mapping of angiogenesis in tumours [45,46].

Outside of the cell, MMPs are a relatively new and interesting target. MMPs are a family of zinc-binding metalloproteinases that participate in the degradation of the extracellular matrix, including the tumour capsule, resulting in tumour metastasis or invasion of the surrounding tissues. Furthermore, MMPs promote tumour growth and spread through the capillary endothelium [47]. MMPs can also promote neovascularisation by assisting in the breakdown of the extracellular matrix surrounding epithelial cells, resulting in weakened cell-cell tight junctions and adhesive connections and eventually migration of these epithelial cells $[48,49]$.

There are also indirect techniques to measure angiogenesis, namely Glucose Transporter (GLUT) expression and hypoxia imaging, or even the recently discovered prostate specific membrane antigen (PSMA). As hypoxia is one of the key driving elements of angiogenesis, it makes sense to target it as a pseudo-target for angiogenesis. The degree of hypoxia if a strong prognostic factor as it is inversely correlated to survival: oxygendeprived cells are highly resistant to therapy including radio- and chemotherapy, and survival of such cells is the primary cause of disease relapse. It is currently not well understood to what degree hypoxia markers can be directly used to visualise angiogenesis, partly because of suboptimal tracers and partly because successful angiogenesis implies a reduction in hypoxia [50].

Several authors demonstrated a co-upregulation in the expression of glucose transporters (GLUTs) and VEGF during 12-, 18-, and $24 \mathrm{~h}$ of severe hypoxia in vivo (xenografts) and in vitro (cell cultures), suggesting a modulation of the glucose kinetics by angiogenesisrelated genes [51,52]. As GLUTs can be targeted with a commonly used tracer ( $\left.\left[{ }^{18} \mathrm{~F}\right]-\mathrm{FDG}\right)$, it is certainly worthwhile to investigate GLUTs as an angiogenesis marker. PSMA, a target well known for visualising prostate cancer, also seems to play a role in angiogenesis in solid tumours [53].

\section{Indirect Targeting of Angiogenesis}

\section{1. $\left[{ }^{18} F\right]-F D G$}

$\left[{ }^{18} \mathrm{~F}\right]-\mathrm{FDG}$ is a well-known and widely used tracer in the field of oncology (and beyond). Given the correlation between $\left[{ }^{18} \mathrm{~F}\right]-\mathrm{FDG}$ 's target GLUT1 expression and angiogenesis, several attempts have been made to use $\left[{ }^{18} \mathrm{~F}\right]-\mathrm{FDG}$ as a tool to monitor angiogenesis in vivo. Mirus et al. showed that both $\left[{ }^{18} \mathrm{~F}\right]$-FDG PET/CT and contrast enhanced $\mathrm{CT}$ are capable to detect parameters closely connected to the degree of tumour vascularization, and could therefore be used beyond its original role of quantifying glucose metabolism [54] Strauss et al. provided some evidence for this hypothesis as $\left[{ }^{18} \mathrm{~F}\right]$-FDG kinetics were shown to be modulated by angiogenesis-related genes: the transport rate for $\left[{ }^{18} \mathrm{~F}\right]-\mathrm{FDG}(\mathrm{k} 1)$ is higher in tumours with a higher expression of VEGF-A and angiopoietin-2 [55]. More recently, Groves et al. observed in a study of 20 patients with early breast carcinoma, a correlation between mean standardised uptake value and endoglin (CD105, a marker for proliferation/angiogenesis) [56].

However, in comparison to direct angiogenesis tracers $\left[{ }^{18} \mathrm{~F}\right]-\mathrm{FDG}$ seems to be inferior. Provost et al. demonstrated this in a preclinical mouse tumour model using bevacizumab and temozolomide, where tumour uptake of $\left[{ }^{68} \mathrm{Ga}\right]-\mathrm{RGD}$, an integrin-specific angiogenesis tracer, was concordant with tumour growth in controls and in treated groups but $\left[{ }^{18} \mathrm{~F}\right]-\mathrm{FDG}$ was not [57]. 
Clinically, Durante et al. showed in a limited study of 10 patients that $\left[{ }^{68} \mathrm{Ga}\right]-$ NODAGA-RGD has a different spatial distribution than $\left[{ }^{18} \mathrm{~F}\right]-F D G$ bringing different tumour information [38]. Toriihara et al. and Vatsa et al. each later confirmed this concept in other small studies, comparing $\left[{ }^{18} \mathrm{~F}\right]-\mathrm{FDG}$ with $\left[{ }^{18} \mathrm{~F}\right]-\mathrm{FPPRGD}_{2}[58,59]$. Guo et al. investigated but found no correlation between micro vessel density (a proliferation-related endothelial cell marker that reflects active angiogenesis) and $\left[{ }^{18} \mathrm{~F}\right]$-FDG uptake using immunohistochemical staining measurements of angiogenesis in NSCLC [60]. This different distribution raises suspicions about the applicability of $\left[{ }^{18} \mathrm{~F}\right]-\mathrm{FDG}$ as a true angiogenesis marker.

$\left[{ }^{18} \mathrm{~F}\right]-\mathrm{FDG}$ does have a clinical use however, as it remains a tracer with strong prognostic power-even when used in reference to angiogenic treatment. Several studies provided evidence that pre-treatment $\left[{ }^{18} \mathrm{~F}\right]$-FDG PET can serve as an imaging biomarker for predicting survival following anti-angiogenic therapy with bevacizumab [61-63].

\subsection{Hypoxia}

Angiogenesis is recognised as an outcome of hypoxia, where signalling of proliferative markers such as VEGF is upregulated [64]. The degree of angiogenesis and vascular remodelling of vessels is one of the different parameters used to distinguish low-grade from high-grade tumours. Cher et al. already demonstrated, in 2006, that there was a strong correlation between tumour grade, angiogenesis markers and a PET hypoxia marker ( $\left[{ }^{18} \mathrm{~F}\right]$-FMISO). $\left[{ }^{18} \mathrm{~F}\right]$-FMISO is a nitroimidazole compound, which may be intracellularly oxidised in normoxic cells. On the other hand, in hypoxic cells, FMISO cannot be oxidised, and it permanently binds to cellular components. The correlation of angiogenesis and hypoxia (imaging) was further investigated by several independent groups [65,66]. Ueda et al. showed in a bevacizumab effectiveness study that non-responders exhibited a higher degree of angiogenesis with more severe hypoxia than responders during treatment [67]. Similarly, in a study by Bekaert et al. $\left[{ }^{18} \mathrm{~F}\right]-$ FMISO PET uptake was closely linked to tumour grade, with high uptake in glioblastomas [68]. Expression of biomarkers of hypoxia and angiogenesis markers (VEGF and others) were significantly higher in the $\left[{ }^{18} \mathrm{~F}\right]-\mathrm{FMISO}$ uptake group. Most importantly, this last study showed that patients without $\left[{ }^{18} \mathrm{~F}\right]-\mathrm{FMISO}$ uptake had a longer survival time than uptake positive patients-indicating a true clinical application.

However, even though VEGF is a major factor implicated in angiogenesis, evidence for VEGF expression in tumours correlating with hypoxia is conflicting [69]. For example, VEGF was ubiquitously expressed throughout tumours in a preclinical study regardless of proximity to capillaries or areas of necrosis. In addition, regions of severe hypoxia did not correlate with areas of upregulated VEGF expression [70].

$\left[{ }^{18} \mathrm{~F}\right]-\mathrm{FMISO}$ is a well-known hypoxia marker that has been shown to be useful as a prognostic marker, in glioma but also in other tumours [71,72], with an uptake mechanism proven to be hypoxia-dependent and glutathione conjugation [73]. Due to suboptimal pharmacokinetics, ${ }^{18} \mathrm{~F}$-FMISO is not ideal for imaging hypoxia however, and alternative tracers are being investigated. For example, $\left[{ }^{64} \mathrm{Cu}\right]$-diacetyl-bis- $\left(N^{4}\right.$-methylthiosemicarbazone) $\left(\left[{ }^{64} \mathrm{Cu}\right]-\mathrm{ATSM}\right)$ has been shown to be superior in terms of imaging performance, and may even play a role as an add-on for anti-angiogenic tumour treatment [40,74-76]. Similar to FMISO, ATSM also demonstrates a strong correlation between the presence of angiogenic markers and the appearance of hypoxic regions.

An alternative hypoxia tracer is $\left[{ }^{18} \mathrm{~F}\right]-\mathrm{FAZA}$, which has improved pharmacokinetics and biodistribution $[77,78]$. Like FMISO, it belongs to the family of nitroimidazole based tracers, which are typically reduced in hypoxic conditions, leading to intracellular binding of oxygen radicals and general trapping. Moreover, FAZA shows a higher tumour to background ratio [79].

$\left.{ }^{[18} \mathrm{F}\right]$-Flortanidazole $\left(\left[{ }^{18} \mathrm{~F}\right]-\mathrm{HX} 4\right)$ was developed and validated both preclinically and clinically as a third-generation nitroimidazole-based tracer, with an even faster clearance and improved distribution [80]. Although we could not find any direct comparison of $\left[{ }^{18} \mathrm{~F}\right]-$ 
HX4 and angiogenesis markers, its improved biodistribution and tumour visualization as demonstrated in several clinical trials make this a strong candidate for future (attempts at) imaging of angiogenesis in hypoxia-rich environments [81-83].

\subsection{Matrix Metalloproteinases (MMPs)}

It is also possible to target markers that are presented on the intercellular matrix. The main effort is on MMPs, as they are key proteolytic enzymes in tumour invasiveness [84]. MMPs are considered mediators of the alterations observed in the tumour microenvironment during cancer progression since they promote amongst others cancer cell signalling, migration, invasion, autophagy and angiogenesis [85]. There are currently 23 known MMPs, with the most focus currently on to the gelatinase-types (MMP-2 and MMP-9).

(2R)-2-[4- $\left(6-\left[{ }^{18} \mathrm{~F}\right]\right.$ Fluorohex-1-ynyl)-benzenesulfonylamino]-3-methylbutyric acid $\left(\left[{ }^{18} \mathrm{~F}\right]-\right.$ SAV03) was developed to visualise MMP-2 [23]. In 2003, they already demonstrated favourable tumour uptake, either by using the tracer directly or as a pro-drug. In 2015, another group labelled another MMP-2 tracer with ${ }^{68} \mathrm{Ga}$, showing moderate tumour to background ratios [24]. However, the degree of correlation to angiogenesis remains to be proven in the field of imaging and more research is needed.

\subsection{Prostate Specific Membrane Antigen (PSMA)}

PSMA is a well-known target for prostate cancer, using PET isotopes for imaging $\left({ }^{68} \mathrm{Ga}\right.$, ${ }^{18} \mathrm{~F}$ ) and $\beta$-emitters $\left({ }^{90} \mathrm{Y},{ }^{177} \mathrm{Lu}\right)$ for therapeutic applications of (metastasised) prostate cancer. Although PSMA is not expressed in non-prostate tumours, nor in healthy vasculature, expression does occur in endothelial cells of tumour-associated neovasculature [86]. Two excellent reviews of PSMA-based imaging in non-prostate imaging have been recently published [53-87], but we would like to briefly present the findings regarding angiogenesis here. The functional role of PSMA in angiogenesis is not clear at this moment, nor is PSMA a requirement for tumour-associated neovascularisation-but PSMA expression is associated to tumours that critically depend on angiogenesis. It has been proposed that PSMA exerts its exopeptidase activity on small peptides, originating from actions by to the endopeptidase matrix metalloproteinase-2, on its own already a candidate target in angiogenesis imaging [88]. The prognostic power of PSMA has been shown in squamous cell carcinoma of the head and neck, osteosarcoma, colorectal cancer, adenocarcinoma of the pancreas, lung cancer and others, demonstrating that PSMA expression appears to reflect prognostically relevant tumour features for several PSMA-expressing tumour entities [53]. However, this does not apply to all tumours; e.g., adrenocortical and gastric carcinomas did not show a correlation between PSMA uptake and tumour staging [53]. Moreover, PSMA has also been proposed for a dual diagnostic and therapeutic approach in triple negative breast cancer, for its ability to target multiple targets within the tumour microenvironment, including newly formed vessels [89].

In addition to the clinical imaging data providing information about the prognostic capability of PSMA, preclinical work has also been done indicating its critical role in regulating angiogenesis and progression of glioblastoma [90]. In this recent work, the authors also showed a possible therapeutic application (outside of prostate cancer).

\section{Direct Targeting of Angiogenesis}

\subsection{VEGF}

VEGF interacting with its receptor tyrosine kinase (VEGFR) is an important mediator of the angiogenesis pathway and consequently a potential imaging target [91-93]. The binding of VEGF to its receptor initiates a signalling cascade that promotes proliferation, migration, and survival of endothelial cells, leading to angiogenesis [94,95]. There are three endothelium-specific tyrosine kinases receptors, VEGFR-1, VEGFR-2 and VEGFR-3, of which mainly VEGFR-2 is overexpressed in a variety of solid tumour cells [8,96-98]. It has been shown that VEGF receptors (VEGFRs) are over-expressed in both grade IV glioma 
vasculature and grade IV glioma cells [99]. Its expression (as determined by histopathology) is shown to correlate negatively with overall patient survival.

VEGF consists of at least six isoforms of a various number of amino acids $(121,145$, $165,183,189$ and 206) produced through alternative splicing, and are active as homodimers linked by disulphide bonds [100]. VEGF121, VEGF165 and VEGF189 are the major forms secreted, of which mainly VEGF121 and VEGF165 are studied as potential tracers. The most studied tracer targeting VEGFR is ${ }^{123}$ I or ${ }^{125}$ I-labelled VEGF165/121, especially in the first decade of this millennium. However, also [ $\left.{ }^{99 \mathrm{~m}} \mathrm{Tc}\right]-\mathrm{VEGF121}$, [111 $\left.\mathrm{In}\right]-\mathrm{VEGF165}$, [ $\left.{ }^{64} \mathrm{Cu}\right]-$ DOTA-VEGF121 and $\left[{ }^{64} \mathrm{Cu}\right.$ ]-VEGF121 have been investigated, as well as two radiolabelled versions of Bevacizumab: [ $\left.{ }^{111} \mathrm{In}\right]-$ Bevacizumab and $\left[{ }^{89} \mathrm{Zr}\right]-$-Bevacizumab.

The basic concept has been shown to work in vitro, as $\mathrm{Li}$ et al. already demonstrated in 2001 that [ $\left.{ }^{123} \mathrm{I}\right]-\mathrm{VEGF} 165$ binds to a variety of human tumour cells/tissues compared with the corresponding normal tissues or normal peripheral blood cells [101]. They also demonstrated this for [ $\left.{ }^{123} \mathrm{I}\right]-$ VEGF121, although to a lesser extent. In the following years, several authors continued this work in preclinical models using non-invasive imaging with iodinated VEGF $[27,102,103]$. Backer et al. prepared a Cys-tagged vector of VEGF121 by cloning two single-chain of VEGF121 joining head-to-tail to express as scVEGF, which can be labelled as $\left[{ }^{64} \mathrm{Cu}\right]-1,4,7,10$-tetraazacyclododecane- $\mathrm{N}, \mathrm{N}^{\prime}, \mathrm{N}^{\prime \prime}, \mathrm{N}^{\prime \prime \prime}$-tetraacetic acid (DOTA)-scVEGF ([ $\left.\left.{ }^{64} \mathrm{Cu}\right]-\mathrm{DOTA}-\mathrm{scVEGF}\right)$ or $\left[{ }^{99 \mathrm{~m}} \mathrm{Tc}\right]$-hydrazinonicotinic acid (HYNIC)scVEGF ([99m Tc]-HYNIC-scVEGF) [104]. They later showed a good and specific tumour to background ratio in a preclinical model for both the ${ }^{99} \mathrm{~m}$ Tc and the ${ }^{64} \mathrm{Cu}$-labelled scVEGF, even though a high degree of heterogeneity was noticed [27]. Aiming for imaging at a later time point, Chan et al. developed a recombinant protein composed of VEGF165 fused through a flexible polypeptide linker to the n-lobe of human transferrin (hnTf), thus allowing labelling without the introduction of a specific chelator [105]. Although showing a reasonable tumour to background ratio, this tracer was found to be insufficiently stable in vivo. Cai et al. and Wang et al. further explored another variant labelled with ${ }^{64} \mathrm{Cu}$, and managed to reduce renal toxicity while maintaining VEGFR specificity $[26,106]$.

Clinical trials with labelled VEGF so far are limited. One example in particular involving staging and follow-up of 18 patients with solid gastrointestinal tumours, $\left[{ }^{123} \mathrm{I}\right]$ VEGF165 scans were compared with CT and MRI, demonstrating the usefulness of the $\left.{ }^{[23} \mathrm{I}\right]-$ VEGF165 scan to visualise the tumour angiogenesis, despite the superiority of CT and MRI for the visualization of the gastrointestinal tumours and metastasis [25]. Li et al. further investigated biodistribution, safety, and dosimetry of [ $\left.{ }^{123} \mathrm{I}\right]-\mathrm{VEGF} 165$ in nine patients with pancreatic carcinomas. They demonstrated that $\left[{ }^{123} \mathrm{I}\right]-\mathrm{VEGF} 165$ visualised the primary tumour and their metastasis, but also noticed severe deiodination thus hampering routine clinical applicability [107]. Ubl et al. further tried to visualise B-cell lymphoma of the Mucosa-Associated Lymphoid Tissue (MALT lymphoma) using [ ${ }^{123}$ I]-VEGF165 in three patients but failed to visualise the tumours. More recently, the World Health Organization (WHO) grade IV glioma lesions were shown to have significant $\left[{ }^{123} \mathrm{I}\right]-V E G F$ uptake $18 \mathrm{~h}$ after the injection, whereas other brain tumours of grade II or III showed negative results in a study with 18 patients [108]. The most important finding was that $\left[{ }^{123} \mathrm{I}\right]$-VEGF scans yielded prognostic information as patients with [ $\left.{ }^{123} \mathrm{I}\right]-\mathrm{VEGF} \mathrm{T} / \mathrm{N}$ ratio above a particular threshold showed significantly longer survival than patients below that threshold ( $2680 \mathrm{vs}$. 295 days).

As few of these VEGF tracers went beyond the preclinical stage, an alternative pathway was explored: radiolabelled Bevacizumab. After preliminary mouse trials, $\left[{ }^{89} \mathrm{Zr}\right]-$ bevacizumab PET was able to visualise tumours in renal carcinoma patients $[28,109]$. High baseline tumour SUV $_{\max }$ was associated with longer time to progression, and Bevacizumab/interferon- $\alpha$ treatment strongly decreased tumour uptake. Even though the tracer showed success in visualising glioma and was able to distinguish grade 4 from lower grade glioma, the authors did show a high interpatient and intra-patient heterogeneity and further clinical application has been modest. The reason for this is the high heterogeneity of VEGFR expression in tumours, leading to disappointing clinical trials both for imaging as 
well as treatment (for example with bevacizumab) [110,111]. Studies are ongoing however; and similar to the $\left[{ }^{123} \mathrm{I}\right]$-VEGF scans $\left[{ }^{89} \mathrm{Zr}\right]$-bevacizumab may prove useful as a prognostic tool, even in children [112].

\subsection{Integrins}

Physiologically, healthy endothelial cells do not or little express integrins: integrins generally characterise a pathological state and are expressed on tumour cells and its associated neo-vasculature [113]. Among integrins, $\alpha \mathrm{v} \beta 3$ is highly expressed in tumours such as osteosarcomas, neuroblastomas, glioblastomas, malignant melanomas, breast, lung and prostate carcinomas and is, therefore, the prime target for imaging. The RGD motif, and the 3-dimensional structure of the ligand, is essential in binding to integrins.

\subsubsection{Fibronectin}

Besides using the RGD-motif in the form of a small peptide integrins can also be targeted using the (much larger) radiolabelled (modified) fibronectin. In vitro and in vivo studies showed good biodistribution and tumour to background ratios for ${ }^{99 \mathrm{~m}} \mathrm{Tc},{ }^{123} \mathrm{I}$, ${ }^{124} \mathrm{I}$ and ${ }^{76} \mathrm{Br}$ labelled human recombinant anti-ED-B fibronectin antibody fragments, but clinical studies were generally not attempted $[30,32,33,114]$.

One clinical study used [ $\left.{ }^{123} \mathrm{I}\right]$-labelled dimeric L19 [L19(scFv)(2)] in 20 patients with lung, colorectal, or brain cancer [31]. This tracer showed a preference for aggressive, actively growing cancers, leading the authors to speculate about possible therapeutic applications.

\subsubsection{RGD-Motif}

The RGD motif is a more "popular" agent to study integrin visualisation when compared to antibody fragments, as the small peptide is easier to produce and handle. Both linear and cyclic RGD peptides can theoretically be used as targeting biomolecules to develop $\alpha_{\mathrm{v}} \beta_{3}$-targeted radiotracers, but although linear peptides showed superior binding affinity in in vitro studies; this was reversed in vivo as well as showing lack of specificity. Most importantly, linear peptides are naturally unstable in vivo due to the high susceptibility to proteases $[115,116]$. The most promising RGD peptides allowing identification and location of the $\alpha_{\mathrm{v}} \beta_{3}$ integrin are small-sized, cyclic, and with a non-natural phenylalanine into the cyclic RGD sequence as these parameters increase affinity and stability (Figure 2).

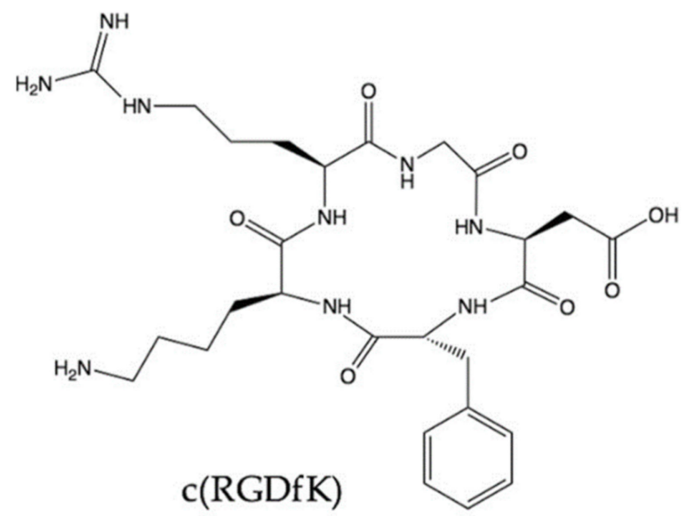

Figure 2. Cyclo(-RGDfK), a potent and selective inhibitor of the $\alpha_{\mathrm{v}} \beta_{3}$ integrin, with an $\mathrm{IC}_{50}$ of $0.94 \mathrm{nM}$.

The first tracers that have been developed were monomers of the RGD sequence. The first RGD adducts were obtained by electrophilic radio-iodination for SPECT imaging, showing correct specificities for $\alpha_{\mathrm{v}} \beta_{3}$ both in vitro and in vivo, but also a strong hepatic and intestinal uptake resulting from their hepatobiliary elimination, thus limiting their applicability [117]. ${ }^{99 \mathrm{~m}} \mathrm{Tc}-$ labelled compounds were also developed, with different bifunc- 
tional chelators. However, they were characterised by a disturbingly high lipophilicity that led to a strong hepatic uptake and elimination [118]. This high liver uptake proved again problematic in a clinical setting [119].

Several variants of RGD have been produced by adding groups to improve the biodistribution and pharmacokinetics. The $\left[{ }^{18} \mathrm{~F}\right]-$ Galacto-RGD, which is RGD with an added glycosylation, is perhaps the most studied integrin-targeting tracer in PET and can be considered as a reference in the study of the expression of $\alpha_{v} \beta_{3}$ [120]. This tracer presented a specific binding both in animal and human studies, fast blood clearance, good pharmacokinetic properties and an uptake corresponding to the expression of $\alpha_{v} \beta_{3}$. Over the past two decades, $\left[{ }^{18} \mathrm{~F}\right]$-Galacto-RGD has been used in a multitude of preclinical and clinical trials, investigating, amongst others, malignant melanomas, glioblastomas, head and neck cancers, sarcomas, renal cell cancers, non-small cells lung cancers (i.e., NSCLC) and prostate cancers. Its main field of application was found to be in glioma, as $\left[{ }^{18} \mathrm{~F}\right]-G a l a c t o-R G D$ did not show a high uptake in normal brain tissue, especially when compared to $\left[{ }^{18} \mathrm{~F}\right]$ FDG [117]. Other variants followed: $\left[{ }^{18} \mathrm{~F}\right]$-Fluciclatide developed by GE Healthcare and $\left[{ }^{18} \mathrm{~F}\right]-$ RGD-K5 developed by Siemens Molecular Imaging Inc. Although they all showed suitable properties in preclinical studies, their long and sometimes complicated synthesis made them unattractive as commercially viable tracers [117].

Next to glycosylation, pegylation was also attempted. When comparing $\left[{ }^{18} \mathrm{~F}\right]-\mathrm{FB}-$ RGD, a fluorobenzoyl-labelled RGD peptide with its pegylated analogue $\left[{ }^{18} \mathrm{~F}\right]-\mathrm{PEG}-\mathrm{RGD}$, Chen et al. found that pegylation resulted in an improved tumour uptake, but also a slowed pharmacokinetics and clearance [37]. [ $\left.{ }^{18} \mathrm{~F}\right]-F P R G D 2$, an RGD-variant with a minipegylation, was found to show improved radiosynthesis yields, equal tumour uptake and reduced renal uptake in a preclinical study [121]. Later clinical studies confirmed its applicability [122-124]. Its uptake did not seem to correlate with that of $\left[{ }^{18} \mathrm{~F}\right]-\mathrm{FDG}$.

Dimerization is another key modification to the RGD motif. Although not adapting the motif as such the inherent increased local concentration of RGD, when in presence of high concentrations of integrins, should lead to an improved affinity. [ $\left.{ }^{18} \mathrm{~F}\right]-\mathrm{FPPRGD} 2$, a dimeric peptide designed by conjugating $\left[{ }^{18} \mathrm{~F}\right]-\mathrm{NFP}$ with pegylated RGD dimeric peptide was also shown to bind to integrin-expressing tumours both in vitro and in vivo. A biodistribution study of $\left[{ }^{18} \mathrm{~F}\right]-F P P R G D 2$ in human revealed promising pharmacokinetic properties [125]. When comparing $\left[{ }^{18} \mathrm{~F}\right]$-FPPRGD2 to $\left[{ }^{18} \mathrm{~F}\right]-\mathrm{FDG}$, no difference was noted for primary lesions as well as metastases [126]. $\left.{ }^{18} \mathrm{~F}\right]-$ FPPRGD2 was slightly superior, as it detected several small metastases that $\left[{ }^{18} \mathrm{~F}\right]$-FDG did not, while it proved negative in inflammatory lymph nodes where $\left[{ }^{18} \mathrm{~F}\right]-F D G$ showed a false positive. Similarly, $\left[{ }^{18} \mathrm{~F}\right]-\mathrm{FPPRGD} 2$ PET showed a higher detection rate of recurrent glioblastoma multiform than that of brain MRI (100.0\% vs. $93.3 \%)$ [127].

The concept of dimerization was taken one step further by synthesising a tetrameric compound $\left[{ }^{18} \mathrm{~F}\right] \mathrm{FB}-\mathrm{mini}$-PEG-E $\{\mathrm{E}[\mathrm{c}(\mathrm{RGDyK})] 2\} 2$; albeit without significant advantages both in vitro and in vivo [128]. Dimerization was also tried for ${ }^{99} \mathrm{~m}$ Tc and ${ }^{68} \mathrm{Ga}$ compoundsagain modifying the kinetics but generally maintaining tumour to background ratio [129-131]. The positive effect of multimerization on tumour uptake was also demonstrated in ${ }^{64} \mathrm{Cu}$ labeled octameric RGD-peptide as well as [ $\left.{ }^{111} \mathrm{In}\right]$-labelled monomeric, dimeric and tetrameric analogues $[132,133]$. Even more octamer peptides have been studied with other isotopes, with similar good-but-not-superior results [134-136]. Cyclic mono or multimeric peptides, labelled with ${ }^{68} \mathrm{Ga}$ through a chelator, may also prove to have a future, although a headto-head clinical comparison is still missing [57,137-140]. Using the chelator as a positive concept in the RGD structure, some researchers even head back to ${ }^{18} \mathrm{~F}$ and investigate ${ }^{18}$ F-labelled NOTA-RGD variants [141].

The added clinical value of imaging integrins is still being investigated. For example, $\left[{ }^{18} \mathrm{~F}\right]-F P P R G D 2$ provides additional information when compared to $\left[{ }^{18} \mathrm{~F}\right]-\mathrm{FDG}$ and may even outperform routine brain MRI [127]. In an atypical study in canines, Clemmensen et al. showed that $\left[{ }^{68} \mathrm{Ga}\right] \mathrm{Ga}-\mathrm{NODAGA}-\mathrm{E}[(\mathrm{cRGDyK})] 2$ (RGD) PET and hyperpolarised [1-13C]pyruvate-MRSI (hyperPET) provide supplemental information and made a case 
for a more widespread use of combining angiogenesis imaging with energy metabolism to optimise patient treatment. A human clinical trial confirmed this case, as $\left[{ }^{18} \mathrm{~F}\right]-\mathrm{RGD}$ uptake on PET/CT imaging pre-treatment may predict the response to antiangiogenic therapy, with higher $\left[{ }^{18} \mathrm{~F}\right]-\mathrm{RGD}$ uptake in tumours predicting a better response to apatinib therapy [142].

The question remains which RGD peptide is the optimal choice. Both ${ }^{18} \mathrm{~F},{ }^{68} \mathrm{Ga}$ and

${ }^{99 m}$ Tc labelled tracers have shown good biodistribution and pharmacokinetics as well as tumour uptake in a variety of tumours [58,59,129,143-145]. The added value compared to $\left[{ }^{18} \mathrm{~F}\right]-F D G$ is now emerging, especially in the field of head and neck tumours [146,147], but which tracer that should be integrated into daily clinical routine remains an open question.

\subsection{NGR}

Aminopeptidase N (APN/CD13), together with VEGF and RGD, is a key tumour angiogenesis marker. CD13 plays an important role in peptide cleavage, such as angiotensins, kinins, enkephalins, cytokines and chemokines. It also participates in extracellular matrix protein degradation, facilitating tumour cell invasion and migration.

Several studies reported that CD13 is overexpressed in the endothelial cells of tumour vasculature and in several solid tumours. Due to this increased expression, CD13 was reviewed as an important clinical marker in several inflammatory diseases and malignant cancers [148-150].

Peptides with an NGR (Asn-Gly-Arg) motif have been shown to have a high affinity for CD13 and several analogues have been synthesised over the past decade. The research field, starting with ${ }^{99 \mathrm{~m}} \mathrm{Tc}$, quickly moved from monomeric to multimeric peptides as they showed improved affinity $[39,151,152]$. Several ${ }^{68} \mathrm{Ga}$ and a ${ }^{64} \mathrm{Cu}$ have been developed recently, each demonstrating good tumour to background ratios in preclinical models [41], [153-155]. Kis et al. compared radiolabelled NGR and RGD imaging in a preclinical tumour model and showed that $\left[{ }^{68} \mathrm{Ga}\right]-\mathrm{NOTAc}(\mathrm{NGR})$ of the primary tumours was significantly higher than that of the accumulation of the commercially available $\left[{ }^{68} \mathrm{Ga}\right]-N O D A G A-[c(R G D)]_{2}[40,153]$.

No NGR peptide had been tested in a clinical setting yet, so the clinical value has yet to be proven. In an interesting twist, Gai et al. recently made a dual receptor combining Integrin $\alpha_{\mathrm{v}} \beta_{3}$ and Aminopeptidase $\mathrm{N}$ Dual-Receptor. [ ${ }^{68} \mathrm{Ga}$-NGR-RGD showed higher binding avidities, targeting efficiency and longer tumour retention time compared with monomeric $\left[{ }^{68} \mathrm{Ga}\right]-\mathrm{NGR}$ and $\left[{ }^{68} \mathrm{Ga}\right]-\mathrm{RGD}$ [156]. It may turn out that multimeric, multireceptor peptides are the way to go for clinical applications.

\section{Beyond Imaging}

Driven by the successful clinical applications of $\left[{ }^{177} \mathrm{Lu}\right]-D O T A-T A T E$ and $\left[{ }^{177} \mathrm{Lu}\right]-$ PSMA, both therapeutic agents developed based upon their ${ }^{68} \mathrm{Ga}$-predecessor designed for imaging, research is now also focusing to investigate the possible role of angiogenesis markers as potential therapeutic targets.

Ma et al. combined NGR with VEGF to produce a novel fusion protein labelled with the therapeutic isotope ${ }^{188} \mathrm{Re} .{ }^{188} \mathrm{Re}$ has similar chemical characteristics as ${ }^{99 \mathrm{~m}} \mathrm{Tc}$ but emits an electron in addition to gamma lines that are suitable for SPECT-making the isotope suitable for radionuclide therapy. They demonstrated a favourable tumour to background ratio in HT-1080 tumour xenografts using SPECT, and more importantly showed that when applied in therapeutic concentrations $\left[{ }^{188} \operatorname{Re}\right]$ Re-NGR-VEGI showed excellent tumour inhibition effect with no observable toxicity [157]. Zhao et al. combined RGD with Evans blue and subsequently labelled this peptide analogue with ${ }^{177} \mathrm{Lu}$, another therapeutic isotope. [ $\left.{ }^{177} \mathrm{Lu}\right]-\mathrm{EB}-\mathrm{RGD}$ was shown to have an inhibitory effect on tumour growth, either on its own or in combination with other drugs [158,159]. Translation to clinical routine is not yet a possibility, but the concept of angiogenesis-markers labelled with therapeutic isotopes does have a future. 


\section{Materials and Methods}

The information for this review was compiled from PubMed listed publications, using the following search terms (final search in March 2021):

- Selected reviews: PET imaging angiogenesis (353 results) and SPECT imaging angiogenesis (169 results).

- Original research: PET NGR (15 results), SPECT NGR (7 results), PET VEGF (413 results), SPECT VEGF (153 results), PET RGD (438 results), SPECT RGD (138 results), SPECT EGF (81 results), PET EGF (79 results), PET Fibroblast growth factor (132 results), SPECT Fibroblast growth factor (42 results), PET PDGF (39 results), SPECT PDGF (6 results), SPECT Angiopoietin-1 (3 results), PET Angiopoietin-1 (5 results), SPECT ephrin (2 results), PET ephrin (12 results), PET MMP angiogenesis (14 results) and SPECT MMP angiogenesis (6 results).

The resulting publication lists were subsequently selected only for oncology related publications in animals/humans, disregarding any findings regarding cardiology or vascular plaques and disregarding publications focusing purely on new radiochemical or chemical synthesis pathways.

\section{Conclusions}

Significant progress has been made over the past decade concerning molecular imaging in angiogenesis. While indirect imaging of angiogenesis using either $\left[{ }^{18} \mathrm{~F}\right]-\mathrm{FDG}$ or hypoxia-markers is not always strictly correlated to angiogenesis, they do have strong prognostic power in the clinical setting. Direct imaging with specific markers, targeting specific receptors on the cancer cells or the surrounding vasculature, are more tightly correlated to angiogenesis. Their clinical impact remains to be determined however, as there are a multitude of potentially useful tracers, both preclinical and clinical, but further research is needed to determine which of those will be translated to the clinical setting. In our opinion, the RGD family holds the most potential to enter clinical routine as a tracer for direct quantification of angiogenesis, by providing an improved assessment of tumour characteristics required for personalised therapy approaches.

Author Contributions: All authors participated in the conceptualisation, writing and review of the manuscript. All authors have read and agreed to the published version of the manuscript.

Funding: This research received no external funding.

Institutional Review Board Statement: Not applicable.

Informed Consent Statement: Not applicable.

Data Availability Statement: Data sharing is not applicable. No new data were created or analysed in this study.

Conflicts of Interest: F.M.M. is on the advisory board of Advanced Accelerator Applications GmbH and received institutional grants from GE Healthcare, Siemens and Nano-Mab. All other authors declare no conflict of interest.

\section{References}

1. Folkman, J. Role of angiogenesis in tumor growth and metastasis. Semin. Oncol. 2002, 29, 15-18. [CrossRef]

2. Zetter, B.R. Angiogenesis and tumor metastasis. Annu. Rev. Med. 1998, 49, 407-424. [CrossRef]

3. Chandra, A.; Rick, J.; Yagnik, G.; Aghi, M.K. Autophagy as a mechanism for anti-angiogenic therapy resistance. Semin. Cancer Biol. 2020, 66, 75-88. [CrossRef]

4. Bergers, G.; Hanahan, D. Modes of resistance to anti-angiogenic therapy. Nat. Rev. Cancer 2008, 8, 592-603. [CrossRef]

5. Moawad, A.W.; Szklaruk, J.; Lall, C.; Blair, K.J.; O Kaseb, A.; Kamath, A.; A Rohren, S.; Elsayes, K.M. Angiogenesis in Hepatocellular Carcinoma; Pathophysiology, Targeted Therapy, and Role of Imaging. J. Hepatocell. Carcinoma 2020, 7, 77-89. [CrossRef]

6. Reichardt, W.; von Elverfeldt, D. Preclinical Applications of Magnetic Resonance Imaging in Oncology. In Recent Results in Cancer Research; Springer: Berlin/Heidelberg, Germany, 2020; Volume 216, pp. 405-437. 
7. Nabavizadeh, S.A.; Ware, J.B.; Wolf, R.L. Emerging Techniques in Imaging of Glioma Microenvironment. Top. Magn. Reson. Imaging 2020, 29, 103-114. [CrossRef]

8. Carmeliet, P.; Jain, R.K. Molecular mechanisms and clinical applications of angiogenesis. Nat. Cell Biol. 2011, 473, 298-307. [CrossRef]

9. Yunus, M.; Jansson, P.J.; Kovacevic, Z.; Kalinowski, D.S.; Richardson, D.R. Tumor-induced neoangiogenesis and receptor tyrosine kinases-Mechanisms and strategies for acquired resistance. Biochim. Biophys. Acta (BBA) - Gen. Subj. 2019, 1863, $1217-1225$. [CrossRef]

10. Loizzi, V.; Del Vecchio, V.; Gargano, G.; De Liso, M.; Kardashi, A.; Naglieri, E.; Resta, L.; Cicinelli, E.; Cormio, G. Biological Pathways Involved in Tumor Angiogenesis and Bevacizumab Based Anti-Angiogenic Therapy with Special References to Ovarian Cancer. Int. J. Mol. Sci. 2017, 18, 1967. [CrossRef]

11. Adair, T.H.; Montani, J. Angiogenesis. Morgan Claypool Life Sci. 2010. [CrossRef]

12. De Palma, M.; Biziato, D.; Petrova, T.V. Microenvironmental regulation of tumour angiogenesis. Nat. Rev. Cancer 2017, 17, 457-474. [CrossRef] [PubMed]

13. Nishida, N.; Yano, H.; Nishida, T.; Kamura, T.; Kojiro, M. Angiogenesis in cancer. Vasc. Heal. Risk Manag. 2006, 2, 213-219. [CrossRef]

14. Ausprunk, D.H.; Folkman, J. Migration and proliferation of endothelial cells in preformed and newly formed blood vessels during tumor angiogenesis. Microvasc. Res. 1977, 14, 53-65. [CrossRef]

15. Döme, B.; Hendrix, M.J.; Paku, S.; Tóvári, J.; Tímár, J. Alternative Vascularization Mechanisms in Cancer: Pathology and Therapeutic Implications. Am. J. Pathol. 2007, 170, 1-15. [CrossRef]

16. Avraamides, C.J.; Garmy-Susini, B.; Varner, J.A. Integrins in angiogenesis and lymphangiogenesis. Nat. Rev. Cancer 2008, 8, 604-617. [CrossRef]

17. Hanahan, D.; Weinberg, R.A. Hallmarks of Cancer: The Next Generation. Cell 2011, 144, 646-674. [CrossRef]

18. Brown, L.F.; Detmar, M.; Claffey, K.; Nagy, J.A.; Feng, D.; Dvorak, A.M.; Dvorak, H.F. Vascular permeability factor/vascular endothelial growth factor:A multifunctional angiogenic cytokine. Galanin 1997, 79, 233-269. [CrossRef]

19. Lopes, S.I.L.; Ferreira, S.; Caetano, M. PET/CT in the evaluation of hypoxia for radiotherapy planning in head and neck tumors: Systematic literature review. J. Nucl. Med. Technol. 2020, 120249540. [CrossRef]

20. Lee, S.; Muralidharan, V.; Tebbutt, N.; Wong, P.; Fang, C.; Liu, Z.; Gan, H.; Sachinidis, J.; Pathmaraj, K.; Christophi, C.; et al. Prevalence of hypoxia and correlation with glycolytic metabolism and angiogenic biomarkers in metastatic colorectal carcinoma. Eur. J. Nucl. Med. Mol. Imaging 2021, 48, 1585-1592. [CrossRef]

21. Troost, E.G.; Laverman, P.; Kaanders, J.H.; Oyen, W.J.; Boerman, O.C.; Bussink, J. Intratumoral Spatial Distribution of Hypoxia and Angiogenesis Assessed by 18F-FAZA and 125I-Gluco-RGD Autoradiography. J. Nucl. Med. 2008, 49, 1732. [CrossRef]

22. Saksø, M.; Mortensen, L.S.; Primdahl, H.; Johansen, J.; Kallehauge, J.; Hansen, C.R.; Overgaard, J. Influence of FAZA PET hypoxia and HPV-status for the outcome of head and neck squamous cell carcinoma (HNSCC) treated with radiotherapy: Long-term results from the DAHANCA 24 trial (NCT01017224). Radiother. Oncol. 2020, 151, 126-133. [CrossRef]

23. Furumoto, S.; Takashima, K.; Kubota, K.; Ido, T.; Iwata, R.; Fukuda, H. Tumor detection using 18F-labeled matrix metalloproteinase-2 inhibitor. Nucl. Med. Biol. 2003, 30, 119-125. [CrossRef]

24. Liu, Q.; Pan, D.; Cheng, C.; Zhang, A.; Ma, C.; Wang, L.; Zhang, D.; Liu, H.; Jiang, H.; Wang, T.; et al. Targeting of MMP2 activity in malignant tumors with a 68 Ga-labeled gelatinase inhibitor cyclic peptide. Nucl. Med. Biol. 2015, 42, 939-944. [CrossRef]

25. Li, S.; Peck-Radosavljevic, M.; Kienast, O.; Preitfellner, J.; Hamilton, G.; Kurtaran, A.; Pirich, C.; Angelberger, P.; Dudczak, R. Imaging gastrointestinal tumours using vascular endothelial growth factor-165 (VEGF165) receptor scintigraphy. Ann. Oncol. 2003, 14, 1274-1277. [CrossRef] [PubMed]

26. Wang, H.; Cai, W.; Chen, K.; Li, Z.-B.; Kashefi, A.; He, L.; Chen, X. A new PET tracer specific for vascular endothelial growth factor receptor 2. Eur. J. Nucl. Med. Mol. Imaging 2007, 34, 2001-2010. [CrossRef]

27. Backer, M.V.; Levashova, Z.; Patel, V.; Jehning, B.T.; Claffey, K.; Blankenberg, F.G.; Backer, J.M. Molecular imaging of VEGF receptors in angiogenic vasculature with single-chain VEGF-based probes. Nat. Med. 2007, 13, 504-509. [CrossRef] [PubMed]

28. Nagengast, W.B.; De Vries, E.G.; Hospers, G.A.; Mulder, N.H.; De Jong, J.R.; Hollema, H.; Brouwers, A.H.; Van Dongen, G.A.; Perk, L.R.; Hooge, M.N.L.-D. In Vivo VEGF Imaging with Radiolabeled Bevacizumab in a Human Ovarian Tumor Xenograft. J. Nucl. Med. 2007, 48, 1313-1319. [CrossRef] [PubMed]

29. Desar, I.M.; Stillebroer, A.B.; Oosterwijk, E.; Leenders, W.P.; Van Herpen, C.M.; Van Der Graaf, W.T.; Boerman, O.C.; Mulders, P.F.; Oyen, W.J.G. 111In-Bevacizumab Imaging of Renal Cell Cancer and Evaluation of Neoadjuvant Treatment with the Vascular Endothelial Growth Factor Receptor Inhibitor Sorafenib. J. Nucl. Med. 2010, 51, 1707-1715. [CrossRef]

30. Berndorff, D.; Borkowski, S.; Moosmayer, D.; Viti, F.; Müller-Tiemann, B.; Sieger, S.; Friebe, M.; Hilger, C.S.; Zardi, L.; Neri, D.; et al. Imaging of tumor angiogenesis using $99 \mathrm{mTc}$-labeled human recombinant anti-ED-B fibronectin antibody fragments. J. Nucl. Med. 2006, 47, 1707-1716.

31. Santimaria, M.; Moscatelli, G.; Viale, G.L.; Giovannoni, L.; Neri, G.; Viti, F.; Leprini, A.; Borsi, L.; Castellani, P.; Zardi, L.; et al. Immunoscintigraphic detection of the ED-B domain of fibronectin, a marker of angiogenesis, in patients with cancer. Clin. Cancer Res. 2003, 9, 571-579. 
32. Tijink, B.M.; Perk, L.R.; Budde, M.; Walsum, M.S.-V.; Visser, G.W.M.; Kloet, R.W.; Dinkelborg, L.M.; Leemans, C.R.; Neri, D.; Van Dongen, G.A.M.S. 124I-L19-SIP for immuno-PET imaging of tumour vasculature and guidance of 131I-L19-SIP radioimmunotherapy. Eur. J. Nucl. Med. Mol. Imaging 2009, 36, 1235-1244. [CrossRef] [PubMed]

33. Rossin, R.; Berndorff, D.; Friebe, M.; Dinkelborg, L.M.; Welch, M.J. Small-Animal PET of Tumor Angiogenesis Using a 76BrLabeled Human Recombinant Antibody Fragment to the ED-B Domain of Fibronectin. J. Nucl. Med. 2007, 48, 1172-1179. [CrossRef] [PubMed]

34. Beer, A.J.; Haubner, R.; Sarbia, M.; Goebel, M.; Luderschmidt, S.; Grosu, A.L.; Schnell, O.; Niemeyer, M.; Kessler, H.; Wester, H.-J.; et al. Positron Emission Tomography Using [18F]Galacto-RGD Identifies the Level of Integrin $\alpha \mathrm{v} \beta 3$ Expression in Man. Clin. Cancer Res. 2006, 12, 3942-3949. [CrossRef] [PubMed]

35. Sharma, R.; Valls, P.O.; Inglese, M.; Dubash, S.; Chen, M.; Gabra, H.; Montes, A.; Challapalli, A.; Arshad, M.; Tharakan, G.; et al. [18F]Fluciclatide PET as a biomarker of response to combination therapy of pazopanib and paclitaxel in platinumresistant/refractory ovarian cancer. Eur. J. Nucl. Med. Mol. Imaging 2020, 47, 1239-1251. [CrossRef] [PubMed]

36. Doss, M.; Kolb, H.C.; Zhang, J.J.; Bélanger, M.-J.; Stubbs, J.B.; Stabin, M.G.; Hostetler, E.D.; Alpaugh, R.K.; Von Mehren, M.; Walsh, J.C.; et al. Biodistribution and Radiation Dosimetry of the Integrin Marker 18F-RGD-K5 Determined from Whole-Body PET/CT in Monkeys and Humans. J. Nucl. Med. 2012, 53, 787-795. [CrossRef] [PubMed]

37. Chen, X.; Park, R.; Hou, Y.; Khankaldyyan, V.; Gonzales-Gomez, I.; Tohme, M.; Bading, J.R.; Laug, W.E.; Conti, P.S. MicroPET imaging of brain tumor angiogenesis with 18F-labeled PEGylated RGD peptide. Eur. J. Nucl. Med. Mol. Imaging 2004, 31, 1081-1089. [CrossRef]

38. Durante, S.; Dunet, V.; Gorostidi, F.; Mitsakis, P.; Schaefer, N.; Delage, J.; Prior, J.O. Head and neck tumors angiogenesis imaging with 68Ga-NODAGA-RGD in comparison to 18F-FDG PET/CT: A pilot study. EJNMMI Res. 2020, 10, 1-11. [CrossRef]

39. Ma, W.; Wang, Z.; Yang, W.; Ma, X.; Kang, F.; Wang, J. Biodistribution and SPECT Imaging Study of99mTc Labeling NGR Peptide in Nude Mice Bearing Human HepG2 Hepatoma. BioMed Res. Int. 2014, 2014, 1-6. [CrossRef]

40. Kis, A.; Szabó, J.P.; Dénes, N.; Vágner, A.; Nagy, G.; Garai, I.; Fekete, A.; Szikra, D.; Hajdu, I.; Matolay, O.; et al. In Vivo Imaging of Hypoxia and Neoangiogenesis in Experimental Syngeneic Hepatocellular Carcinoma Tumor Model Using Positron Emission Tomography. BioMed Res. Int. 2020, 2020, 1-10. [CrossRef]

41. Li, G.; Wang, X.; Zong, S.; Wang, J.; Conti, P.S.; Chen, K. MicroPET Imaging of CD13 Expression Using a 64Cu-Labeled Dimeric NGR Peptide Based on Sarcophagine Cage. Mol. Pharm. 2014, 11, 3938-3946. [CrossRef]

42. Carmeliet, P. VEGF as a Key Mediator of Angiogenesis in Cancer. Oncology 2005, 69, 4-10. [CrossRef] [PubMed]

43. Duro-Castano, A.; Gallon, E.; Decker, C.; Vicent, M.J. Modulating angiogenesis with integrin-targeted nanomedicines. Adv. Drug Deliv. Rev. 2017, 119, 101-119. [CrossRef] [PubMed]

44. Hoshino, A.; Costa-Silva, B.; Shen, T.-L.; Rodrigues, G.; Hashimoto, A.; Mark, M.T.; Molina, H.; Kohsaka, S.; Di Giannatale, A.; Ceder, S.; et al. Tumour exosome integrins determine organotropic metastasis. Nature 2015, 527, 329-335. [CrossRef] [PubMed]

45. Brooks, P.C.; Montgomery, A.M.; Rosenfeld, M.; Reisfeld, R.A.; Hu, T.; Klier, G.; Cheresh, D.A. Integrin $\alpha$ v $\beta 3$ antagonists promote tumor regression by inducing apoptosis of angiogenic blood vessels. Cell 1994, 79, 1157-1164. [CrossRef]

46. Brooks, P.; Clark, R.; Cheresh, D.; Huang, A.; Golumbek, P.; Ahmadzadeh, M.; Jaffee, E.; Pardoll, D.; Levitsky, H. Requirement of vascular integrin alpha v beta 3 for angiogenesis. Science 1994, 264, 569-571. [CrossRef]

47. Quail, D.F.; A Joyce, J. Microenvironmental regulation of tumor progression and metastasis. Nat. Med. 2013, 19, 1423-1437. [CrossRef]

48. Yu, D.; Ye, T.; Xiang, Y.; Shi, Z.; Zhang, J.; Lou, B.; Zhang, F.; Chen, B.; Zhou, M. Quercetin inhibits epithelial-mesenchymal transition, decreases invasiveness and metastasis, and reverses IL-6 induced epithelial-mesenchymal transition, expression of MMP by inhibiting STAT3 signaling in pancreatic cancer cells. OncoTargets Ther. 2017, 10, 4719-4729. [CrossRef]

49. Thiery, J.P. Epithelial-mesenchymal transitions in tumour progression. Nat. Rev. Cancer 2002, 2, 442-454. [CrossRef]

50. Busk, M.; Overgaard, J.; Horsman, M.R. Imaging of Tumor Hypoxia for Radiotherapy: Current Status and Future Directions. Semin. Nucl. Med. 2020, 50, 562-583. [CrossRef]

51. Pedersen, M.W.; Holm, S.; Lund, E.L.; Hojgaard, L.; Kristjansen, P.E. Coregulation of Glucose Uptake and Vascular Endothelial Growth Factor (VEGF) in Two Small-Cell Lung Cancer (SCLC) Sublines In Vivo and In Vitro. Neoplasia 2001, 3, 80-87. [CrossRef]

52. Airley, R.E.; Mobasheri, A. Hypoxic Regulation of Glucose Transport, Anaerobic Metabolism and Angiogenesis in Cancer: Novel Pathways and Targets for Anticancer Therapeutics. Chemotherapy 2007, 53, 233-256. [CrossRef] [PubMed]

53. Backhaus, P.; Noto, B.; Avramovic, N.; Grubert, L.S.; Huss, S.; Bögemann, M.; Stegger, L.; Weckesser, M.; Schäfers, M.; Rahbar, K. Targeting PSMA by radioligands in non-prostate disease-current status and future perspectives. Eur. J. Nucl. Med. Mol. Imaging 2018, 45, 860-877. [CrossRef] [PubMed]

54. Mirus, M.; Tokalov, S.V.; Abramyuk, A.; Heinold, J.; Prochnow, V.; Zöphel, K.; Kotzerke, J.; Abolmaali, N. Noninvasive assessment and quantification of tumor vascularization using [18F]FDG-PET/CT and CE-CT in a tumor model with modifiable angiogenesis-An animal experimental prospective cohort study. EJNMMI Res. 2019, 9, 55. [CrossRef] [PubMed]

55. Strauss, L.G.; Koczan, D.; Klippel, S.; Pan, L.; Cheng, C.; Willis, S.; Haberkorn, U.; Dimitrakopoulou-Strauss, A. Impact of Angiogenesis-Related Gene Expression on the Tracer Kinetics of 18F-FDG in Colorectal Tumors. J. Nucl. Med. 2008, 49, 1238-1244. [CrossRef] 
56. Groves, A.M.; Shastry, M.; Rodriguez-Justo, M.; Malhotra, A.; Endozo, R.; Davidson, T.; Kelleher, T.; Miles, K.A.; Ell, P.J.; Keshtgar, M.R. 18F-FDG PET and biomarkers for tumour angiogenesis in early breast cancer. Eur. J. Nucl. Med. Mol. Imaging 2010, 38, 46-52. [CrossRef]

57. Provost, C.; Rozenblum-Beddok, L.; Nataf, V.; Merabtene, F.; Prignon, A.; Talbot, J.-N. [68Ga]RGD Versus [18F]FDG PET Imaging in Monitoring Treatment Response of a Mouse Model of Human Glioblastoma Tumor with Bevacizumab and/or Temozolomide. Mol. Imaging Biol. 2019, 21, 297-305. [CrossRef]

58. Toriihara, A.; Duan, H.; Thompson, H.M.; Park, S.; Hatami, N.; Baratto, L.; Fan, A.C.; Iagaru, A. 18F-FPPRGD2 PET/CT in patients with metastatic renal cell cancer. Eur. J. Nucl. Med. Mol. Imaging 2019, 46, 1518-1523. [CrossRef]

59. Vatsa, R.; Ashwathanarayana, A.G.; Singh, G.; Kavanal, A.J.; Kumar, S.; Rana, N.; Shukla, J.; Mittal, B.R. A Comparison of Angiogenesis and Glycolytic Imaging in Patients With Clinical Suspected Locally Advanced Breast Cancer. Clin. Nucl. Med. 2019, 44, e479-e483. [CrossRef]

60. Guo, J.; Higashi, K.; Ueda, Y.; Oguchi, M.; Takegami, T.; Toga, H.; Sakuma, T.; Yokota, H.; Katsuda, S.; Tonami, H.; et al. Microvessel density: Correlation with 18F-FDG uptake and prognostic impact in lung adenocarcinomas. J. Nucl. Med. 2006, 47, 419-425.

61. Colavolpe, C.; Chinot, O.; Metellus, P.; Mancini, J.; Barrie, M.; Bequet-Boucard, C.; Tabouret, E.; Mundler, O.; Figarella-Branger, D.; Guedj, E. FDG-PET predicts survival in recurrent high-grade gliomas treated with bevacizumab and irinotecan. Neuro-Oncology 2012, 14, 649-657. [CrossRef]

62. De Bruyne, S.; Van Damme, N.; Smeets, P.A.M.; Ferdinande, L.; Ceelen, W.; Mertens, J.C.; Van De Wiele, C.; Troisi, R.; Libbrecht, L.; Laurent, S.; et al. Value of DCE-MRI and FDG-PET/CT in the prediction of response to preoperative chemotherapy with bevacizumab for colorectal liver metastases. Br. J. Cancer 2012, 106, 1926-1933. [CrossRef] [PubMed]

63. Hwang, S.H.; Cho, A.; Yun, M.; Choi, Y.D.; Rha, S.Y.; Kang, W.J. Prognostic Value of Pretreatment Metabolic Tumor Volume and Total Lesion Glycolysis Using 18F-FDG PET/CT in Patients With Metastatic Renal Cell Carcinoma Treated With Anti-Vascular Endothelial Growth Factor-Targeted Agents. Clin. Nucl. Med. 2017, 42, e235-e241. [CrossRef]

64. Rajendran, J.G.; Krohn, K.A. Imaging hypoxia and angiogenesis in tumors. Radiol. Clin. North Am. 2005, 43, 169-187. [CrossRef]

65. Lee, S.T.; Scott, A.M. Hypoxia Positron Emission Tomography Imaging With 18F-Fluoromisonidazole. Semin. Nucl. Med. 2007, 37, 451-461. [CrossRef] [PubMed]

66. Rajendran, J.G.; Krohn, K.A. F-18 Fluoromisonidazole for Imaging Tumor Hypoxia: Imaging the Microenvironment for Personalized Cancer Therapy. Semin. Nucl. Med. 2015, 45, 151-162. [CrossRef] [PubMed]

67. Ueda, S.; Saeki, T.; Osaki, A.; Yamane, T.; Kuji, I. Bevacizumab Induces Acute Hypoxia and Cancer Progression in Patients with Refractory Breast Cancer: Multimodal Functional Imaging and Multiplex Cytokine Analysis. Clin. Cancer Res. 2017, 23, 5769-5778. [CrossRef] [PubMed]

68. Bekaert, L.; Valable, S.; Lechapt-Zalcman, E.; Ponte, K.; Collet, S.; Constans, J.-M.; Levallet, G.; Bordji, K.; Petit, E.; Branger, P.; et al. [18F]-FMISO PET study of hypoxia in gliomas before surgery: Correlation with molecular markers of hypoxia and angiogenesis. Eur. J. Nucl. Med. Mol. Imaging 2017, 44, 1383-1392. [CrossRef] [PubMed]

69. Machein, M.R.; Plate, K.H. VEGF in Brain Tumors. J. Neuro-Oncol. 2000, 50, 109-120. [CrossRef]

70. Parliament, M.B.; Allalunis-Turner, M.J.; Franko, A.J.; Olive, P.L.; Mandyam, R.; Santos, C.; Wolokoff, B. Vascular endothelial growth factor expression is independent of hypoxia in human malignant glioma spheroids and tumours. Br. J. Cancer 2000, 82, 635-641. [CrossRef]

71. Sorace, A.G.; Elkassem, A.A.; Galgano, S.J.; Lapi, S.E.; Larimer, B.M.; Partridge, S.C.; Quarles, C.C.; Reeves, K.; Napier, T.S.; Song, P.N.; et al. Imaging for Response Assessment in Cancer Clinical Trials. Semin. Nucl. Med. 2020, 50, 488-504. [CrossRef]

72. Hirata, K.; Yamaguchi, S.; Shiga, T.; Kuge, Y.; Tamaki, N. The Roles of Hypoxia Imaging Using 18F-Fluoromisonidazole Positron Emission Tomography in Glioma Treatment. J. Clin. Med. 2019, 8, 1088. [CrossRef] [PubMed]

73. Masaki, Y.; Shimizu, Y.; Yoshioka, T.; Nishijima, K.-I.; Zhao, S.; Higashino, K.; Numata, Y.; Tamaki, N.; Kuge, Y. FMISO accumulation in tumor is dependent on glutathione conjugation capacity in addition to hypoxic state. Ann. Nucl. Med. 2017, 31, 596-604. [CrossRef]

74. Dearling, J.L.; Packard, A.B. Some thoughts on the mechanism of cellular trapping of Cu(II)-ATSM. Nucl. Med. Biol. 2010, 37, 237-243. [CrossRef] [PubMed]

75. Bourgeois, M.; Rajerison, H.; Guerard, F.; Mougin-Degraef, M.; Barbet, J.; Michel, N.; Cherel, M.; Faivre-Chauvet, A. Contribution of [64Cu]-ATSM PET in molecular imaging of tumour hypoxia compared to classical [18F]-MISO-A selected review. Nucl. Med. Rev. 2011, 14, 90-95. [CrossRef] [PubMed]

76. Yoshii, Y.; Yoshimoto, M.; Matsumoto, H.; Furukawa, T.; Zhang, M.-R.; Inubushi, M.; Tsuji, A.B.; Fujibayashi, Y.; Higashi, T.; Saga, T. 64Cu-ATSM internal radiotherapy to treat tumors with bevacizumab-induced vascular decrease and hypoxia in human colon carcinoma xenografts. Oncotarget 2017, 8, 88815-88826. [CrossRef] [PubMed]

77. Quartuccio, N. The Validation Path of Hypoxia PET Imaging: Focus on Brain Tumours. Curr. Med. Chem. 2018, 25, 3074-3095. [CrossRef]

78. Li, F.; Joergensen, J.T.; E Hansen, A.; Kjaer, A. Kinetic modeling in PET imaging of hypoxia. Am. J. Nucl. Med. Mol. Imaging 2014, $4,490-506$

79. Stieb, S.; Eleftheriou, A.; Warnock, G.; Guckenberger, M.; Riesterer, O. Longitudinal PET imaging of tumor hypoxia during the course of radiotherapy. Eur. J. Nucl. Med. Mol. Imaging 2018, 45, 2201-2217. [CrossRef] 
80. Sanduleanu, S.; Van Der Wiel, A.M.; Lieverse, R.I.; Marcus, D.; Ibrahim, A.; Primakov, S.; Wu, G.; Theys, J.; Yaromina, A.; Dubois, L.; et al. Hypoxia PET Imaging with [18F]-HX4-A Promising Next-Generation Tracer. Cancers 2020, 12, 1322. [CrossRef]

81. Zegers, C.M.; Van Elmpt, W.; Reymen, B.; Even, A.J.; Troost, E.; Ollers, M.C.; Hoebers, F.J.P.; Houben, R.M.; Eriksson, J.; Windhorst, A.D.; et al. In Vivo Quantification of Hypoxic and Metabolic Status of NSCLC Tumors Using [18F]HX4 and [18F]FDG-PET/CT Imaging. Clin. Cancer Res. 2014, 20, 6389-6397. [CrossRef]

82. Van Elmpt, W.; Zegers, C.M.L.; Reymen, B.; Even, A.J.G.; Dingemans, A.-M.C.; Oellers, M.; Wildberger, J.E.; Mottaghy, F.M.; Das, M.; Troost, E.; et al. Multiparametric imaging of patient and tumour heterogeneity in non-small-cell lung cancer: Quantification of tumour hypoxia, metabolism and perfusion. Eur. J. Nucl. Med. Mol. Imaging 2016, 43, 240-248. [CrossRef] [PubMed]

83. Zegers, C.M.L.; Hoebers, F.J.P.; Van Elmpt, W.; Bons, J.A.; Öllers, M.C.; Troost, E.; Eekers, D.; Balmaekers, L.; Arts-Pechtold, M.; Mottaghy, F.M.; et al. Evaluation of tumour hypoxia during radiotherapy using [18F]HX4 PET imaging and blood biomarkers in patients with head and neck cancer. Eur. J. Nucl. Med. Mol. Imaging 2016, 43, 2139-2146. [CrossRef] [PubMed]

84. Piperigkou, Z.; Kyriakopoulou, K.; Koutsakis, C.; Mastronikolis, S.; Karamanos, N. Key Matrix Remodeling Enzymes: Functions and Targeting in Cancer. Cancers 2021, 13, 1441. [CrossRef] [PubMed]

85. Gialeli, C.; Theocharis, A.D.; Karamanos, N.K. Roles of matrix metalloproteinases in cancer progression and their pharmacological targeting. FEBS J. 2010, 278, 16-27. [CrossRef]

86. Bostwick, D.G.; Pacelli, A.; Blute, M.; Roche, P.; Murphy, G.P. Prostate specific membrane antigen expression in prostatic intraepithelial neoplasia and adenocarcinoma: A study of 184 cases. Cancer 1998, 82, 2256-2261. [CrossRef]

87. O'Keefe, D.S.; Bacich, D.J.; Huang, S.S.; Heston, W.D. A Perspective on the Evolving Story of PSMA Biology, PSMA-Based Imaging, and Endoradiotherapeutic Strategies. J. Nucl. Med. 2018, 59, 1007-1013. [CrossRef]

88. Conway, R.E.; Joiner, K.; Patterson, A.; Bourgeois, D.; Rampp, R.; Hannah, B.C.; McReynolds, S.; Elder, J.M.; Gilfilen, H.; Shapiro, L.H. Prostate specific membrane antigen produces pro-angiogenic laminin peptides downstream of matrix metalloprotease-2. Angiogenesis 2013, 16, 847-860. [CrossRef]

89. Heesch, A.; Maurer, J.; Stickeler, E.; Beheshti, M.; Mottaghy, F.M.; Morgenroth, A. Development of Radiotracers for Breast Cancer-The Tumor Microenvironment as an Emerging Target. Cells 2020, 9, 2334. [CrossRef]

90. Gao, Y.; Zheng, H.; Li, L.; Feng, M.; Chen, X.; Hao, B.; Lv, Z.; Zhou, X.; Cao, Y. Prostate-Specific Membrane Antigen (PSMA) Promotes Angiogenesis of Glioblastoma Through Interacting With ITGB4 and Regulating NF-kB Signaling Pathway. Front. Cell Dev. Biol. 2021, 9. [CrossRef]

91. Kadambi, A.; Carreira, C.M.; O Yun, C.; Padera, T.P.; E Dolmans, D.; Carmeliet, P.; Fukumura, D.; Jain, R.K. Vascular endothelial growth factor (VEGF)-C differentially affects tumor vascular function and leukocyte recruitment: Role of VEGF-receptor 2 and host VEGF-A. Cancer Res. 2001, 61, 2404-2408.

92. Tsuzuki, Y.; Fukumura, D.; Oosthuyse, B.; Koike, C.; Carmeliet, P.; Jain, R.K. Vascular endothelial growth factor (VEGF) modulation by targeting hypoxia-inducible factor-1alpha $\rightarrow$ hypoxia response element $\rightarrow$ VEGF cascade differentially regulates vascular response and growth rate in tumors. Cancer Res. 2000, 60, 6248-6252.

93. Duda, D.G.; Batchelor, T.T.; Willett, C.G.; Jain, R.K. VEGF-targeted cancer therapy strategies: Current progress, hurdles and future prospects. Trends Mol. Med. 2007, 13, 223-230. [CrossRef] [PubMed]

94. Soltau, J.; Drevs, J. Mode of action and clinical impact of VEGF signaling inhibitors. Expert Rev. Anticancer Ther. 2009, 9, 649-662. [CrossRef] [PubMed]

95. McMahon, G. VEGF Receptor Signaling in Tumor Angiogenesis. Oncology 2000, 5, 3-10. [CrossRef] [PubMed]

96. Hicklin, D.J.; Ellis, L.M. Role of the Vascular Endothelial Growth Factor Pathway in Tumor Growth and Angiogenesis. J. Clin. Oncol. 2005, 23, 1011-1027. [CrossRef] [PubMed]

97. Asabella, A.N.; Di Palo, A.; Altini, C.; Ferrari, C.; Rubini, G. Multimodality Imaging in Tumor Angiogenesis: Present Status and Perspectives. Int. J. Mol. Sci. 2017, 18, 1864. [CrossRef] [PubMed]

98. Rudlowski, C.; Pickart, A.-K.; Fuhljahn, C.; Friepoertner, T.; Schlehe, B.; Biesterfeld, S.; Schroeder, W. Prognostic significance of vascular endothelial growth factor expression in ovarian cancer patients: A long-term follow-up. Int. J. Gynecol. Cancer 2006, 16, 183-189. [CrossRef]

99. Bergsland, E.K. Update on Clinical Trials Targeting Vascular Endothelial Growth Factor in Cancer. Am. J. Health Pharm. 2004, 61, S12-S20. [CrossRef]

100. Ferrara, N. Vascular Endothelial Growth Factor: Basic Science and Clinical Progress. Endocr. Rev. 2004, 25, 581-611. [CrossRef]

101. Li, S.; Peck-Radosavljevic, M.; Koller, E.; Koller, F.; Kaserer, K.; Kreil, A.; Kapiotis, S.; Hamwi, A.; Weich, H.A.; Valent, P.; et al Characterization of 123I-vascular endothelial growth factor-binding sites expressed on human tumour cells: Possible implication for tumour scintigraphy. Int. J. Cancer 2001, 91, 789-796. [CrossRef]

102. Yoshimoto, M.; Kinuya, S.; Kawashima, A.; Nishii, R.; Yokoyama, K.; Kawai, K. Radioiodinated VEGF to image tumor angiogenesis in a LS180 tumor xenograft model. Nucl. Med. Biol. 2006, 33, 963-969. [CrossRef] [PubMed]

103. Blankenberg, F.G.; Mandl, S.; Cao, Y.-A.; O'Connell-Rodwell, C.; Contag, C.; Mari, C.; I Gaynutdinov, T.; Vanderheyden, J.-L.; Backer, M.V.; Backer, J.M. Tumor imaging using a standardized radiolabeled adapter protein docked to vascular endothelial growth factor. J. Nucl. Med. 2004, 45, 1373-1380. [PubMed]

104. Backer, M.V.; Patel, V.; Jehning, B.T.; Claffey, K.P.; Backer, J.M. Surface immobilization of active vascular endothelial growth factor via a cysteine-containing tag. Biomaterials 2006, 27, 5452-5458. [CrossRef] [PubMed] 
105. Huang, H.; Wu, J.; Chan, S.; Wang, H.; Wang, C.; Soong, Y. Vascular Endothelial Growth Factor (VEGF) System Expression in Human Fallopian Tube with Ectopic Pregnancy. Fertil. Steril. 2005, 84, S436. [CrossRef]

106. Cai, W.; Chen, K.; Mohamedali, K.A.; Cao, Q.; Gambhir, S.S.; Rosenblum, M.G.; Chen, X. PET of vascular endothelial growth factor receptor expression. J. Nucl. Med. 2006, 47, 2048-2056.

107. Li, S.; Peck-Radosavljevic, M.; Kienast, O.; Preitfellner, J.; Havlik, E.; Schima, W.; Traub-Weidinger, T.; Graf, S.; Beheshti, M.; Schmid, M.; et al. Iodine-123-vascular endothelial growth factor-165 (123I-VEGF165). Biodistribution, safety and radiation dosimetry in patients with pancreatic carcinoma. QJ Nucl. Med. Mol. Imaging 2004, 48, 198-206.

108. Rainer, E.; Wang, H.; Traub-Weidinger, T.; Widhalm, G.; Fueger, B.; Chang, J.; Zhu, Z.; Marosi, C.; Haug, A.; Hacker, M.; et al. The prognostic value of [123I]-vascular endothelial growth factor ([123I]-VEGF) in glioma. Eur. J. Nucl. Med. Mol. Imaging 2018, 45, 2396-2403. [CrossRef]

109. Oosting, S.F.; Brouwers, A.H.; Van Es, S.C.; Nagengast, W.B.; Munnink, T.H.O.; Hooge, M.N.L.-D.; Hollema, H.; De Jong, J.R.; De Jong, I.J.; De Haas, S.; et al. 89Zr-Bevacizumab PET Visualizes Heterogeneous Tracer Accumulation in Tumor Lesions of Renal Cell Carcinoma Patients and Differential Effects of Antiangiogenic Treatment. J. Nucl. Med. 2014, 56, 63-69. [CrossRef]

110. Chinot, O.L.; Wick, W.; Mason, W.; Henriksson, R.; Saran, F.; Nishikawa, R.; Carpentier, A.F.; Hoang-Xuan, K.; Kavan, P.; Cernea, D.; et al. Bevacizumab plus Radiotherapy-Temozolomide for Newly Diagnosed Glioblastoma. N. Engl. J. Med. 2014, 370, 709-722. [CrossRef]

111. Gilbert, M.R.; Dignam, J.J.; Armstrong, T.S.; Wefel, J.S.; Blumenthal, D.T.; Vogelbaum, M.A.; Colman, H.; Chakravarti, A.; Pugh, S.; Won, M.; et al. A Randomized Trial of Bevacizumab for Newly Diagnosed Glioblastoma. N. Engl. J. Med. 2014, 370, 699-708. [CrossRef]

112. Jansen, M.H.; Van Zanten, S.E.V.; Van Vuurden, D.G.; Huisman, M.C.; Vugts, D.J.; Hoekstra, O.S.; Van Dongen, G.A.; Kaspers, G.-J.L. Molecular Drug Imaging:89Zr-Bevacizumab PET in Children with Diffuse Intrinsic Pontine Glioma. J. Nucl. Med. 2016, 58, 711-716. [CrossRef] [PubMed]

113. Takada, Y.; Ye, X.; Simon, S. The integrins. Genome Biol. 2007, 8, 1-9. [CrossRef]

114. Tarli, L.; Balza, E.; Viti, F.; Borsi, L.; Castellani, P.; Berndorff, D.; Dinkelborg, L.; Neri, D.; Zardi, L. A High-Affinity Human Antibody That Targets Tumoral Blood Vessels. Blood 1999, 94, 192-198. [CrossRef]

115. Bogdanowich-Knipp, S.J.; Chakrabarti, S.; Siahaan, T.J.; Williams, T.D.; Dillman, R.K. Solution stability of linear vs. cyclic RGD peptides. J. Pept. Res. 1999, 53, 530-541. [CrossRef] [PubMed]

116. Tornesello, A.L.; Buonaguro, L.; Tornesello, M.L.; Buonaguro, F.M. New Insights in the Design of Bioactive Peptides and Chelating Agents for Imaging and Therapy in Oncology. Molecules 2017, 22, 1282. [CrossRef] [PubMed]

117. Chen, H.; Niu, G.; Wu, H.; Chen, X. Clinical Application of Radiolabeled RGD Peptides for PET Imaging of Integrin $\alpha v \beta 3$. Theranostics 2016, 6, 78-92. [CrossRef]

118. Decristoforo, C.; Santos, I.; Pietzsch, H.J.; Kuenstler, J.U.; Duatti, A.; Smith, C.J.; Rey, A.; Alberto, R.; Von Guggenberg, E.; Haubner, R. Comparison of in vitro and in vivo properties of [99mTc]cRGD peptides labeled using different novel Tc-cores. QJ Nucl. Med. Mol. Imaging 2007, 51, 33-41.

119. Axelsson, R.; Bach-Gansmo, T.; Castell-Conesa, J.; McParland, B.J. An open-label, multicenter, phase $2 \mathrm{a}$ study to assess the feasibility of imaging metastases in late-stage cancer patients with the $\alpha \mathrm{v} \beta 3$-selective angiogenesis imaging agent $99 \mathrm{mTc}$ NC100692. Acta Radiol. 2010, 51, 40-46. [CrossRef]

120. Haubner, R.; A Weber, W.; Beer, A.J.; Vabuliene, E.; Reim, D.; Sarbia, M.; Becker, K.-F.; Goebel, M.; Hein, R.; Wester, H.-J.; et al. Noninvasive Visualization of the Activated $\alpha v \beta 3$ Integrin in Cancer Patients by Positron Emission Tomography and [18F]Galacto-RGD. PLoS Med. 2005, 2, e70. [CrossRef]

121. Wu, Z.; Li, Z.-B.; Cai, W.; He, L.; Chin, F.T.; Li, F.; Chen, X. 18F-labeled mini-PEG spacered RGD dimer (18F-FPRGD2): Synthesis and microPET imaging of $\alpha \mathrm{v} \beta 3$ integrin expression. Eur. J. Nucl. Med. Mol. Imaging 2007, 34, 1823-1831. [CrossRef]

122. Gao, S.; Wu, H.; Li, W.; Zhao, S.; Teng, X.; Lu, H.; Hu, X.; Wang, S.; Yu, J.; Yuan, S. A pilot study imaging integrin $\alpha v \beta 3$ with RGD PET/CT in suspected lung cancer patients. Eur. J. Nucl. Med. Mol. Imaging 2015, 42, 2029-2037. [CrossRef]

123. Withofs, N.; Signolle, N.; Somja, J.; Lovinfosse, P.; Nzaramba, E.M.; Mievis, F.; Giacomelli, F.; Waltregny, D.; Cataldo, D.; Gambhir S.S.; et al. 18F-FPRGD2 PET/CT Imaging of Integrin v 3 in Renal Carcinomas: Correlation with Histopathology. J. Nucl. Med. 2015, 56, 361-364. [CrossRef] [PubMed]

124. Withofs, N.; Charlier, E.; Simoni, P.; Alvarez-Miezentseva, V.; Mievis, F.; Giacomelli, F.; Mella, C.; Gambhir, S.S.; Malaise, O.; De Seny, D.; et al. 18F-FPRGD2 PET/CT imaging of musculoskeletal disorders. Ann. Nucl. Med. 2015, 29, 839-847. [CrossRef]

125. Mittra, E.S.; Goris, M.L.; Iagaru, A.H.; Kardan, A.; Burton, L.; Berganos, R.; Chang, E.; Liu, S.; Shen, B.; Chin, F.T.; et al. Pilot Pharmacokinetic and Dosimetric Studies of18F-FPPRGD2: A PET Radiopharmaceutical Agent for Imaging $\alpha v \beta 3$ Integrin Levels. Radiology 2011, 260, 182-191. [CrossRef] [PubMed]

126. Minamimoto, R.; Jamali, M.; Barkhodari, A.; Mosci, C.; Mittra, E.; Shen, B.; Chin, F.; Gambhir, S.S.; Iagaru, A. Biodistribution of the 18F-FPPRGD2 PET radiopharmaceutical in cancer patients: An atlas of SUV measurements. Eur. J. Nucl. Med. Mol. Imaging 2015, 42, 1850-1858. [CrossRef] [PubMed]

127. Iagaru, A.; Mosci, C.; Mittra, E.; Zaharchuk, G.; Fischbein, N.; Harsh, G.; Li, G.; Nagpal, S.; Recht, L.; Gambhir, S.S. Glioblastoma Multiforme Recurrence: An Exploratory Study of18F FPPRGD2PET/CT. Radiology 2015, 277, 497-506. [CrossRef] [PubMed]

128. Wu, Z.; Li, Z.-B.; Chen, K.; Cai, W.; He, L.; Chin, F.T.; Li, F.; Chen, X. microPET of Tumor Integrin v 3 Expression Using 18F-Labeled PEGylated Tetrameric RGD Peptide (18F-FPRGD4). J. Nucl. Med. 2007, 48, 1536-1544. [CrossRef] 
129. Lobeek, D.; Rijpkema, M.; Terry, S.Y.A.; Molkenboer-Kuenen, J.D.M.; Joosten, L.; Van Genugten, E.A.J.; Grunsven, A.C.H.V.E.-V.; Kaanders, J.H.A.M.; Pegge, S.A.H.; Boerman, O.C.; et al. Imaging angiogenesis in patients with head and neck squamous cell carcinomas by [68Ga]Ga-DOTA-E-[c(RGDfK)]2 PET/CT. Eur. J. Nucl. Med. Mol. Imaging 2020, 47, 2647-2655. [CrossRef]

130. Shi, J.; Wang, L.; Kim, Y.-S.; Zhai, S.; Liu, Z.; Chen, X.; Liu, S. Improving Tumor Uptake and Excretion Kinetics of 99mTc-Labeled Cyclic Arginine-Glycine-Aspartic (RGD) Dimers with Triglycine Linkers. J. Med. Chem. 2008, 51, 7980-7990. [CrossRef]

131. Wang, J.; Kim, Y.-S.; Liu, S. 99mTc-Labeling of HYNIC-Conjugated Cyclic RGDfK Dimer and Tetramer Using EDDA as Coligand. Bioconjugate Chem. 2008, 19, 634-642. [CrossRef]

132. Dijkgraaf, I.; Liu, S.; Kruijtzer, J.A.; Soede, A.C.; Oyen, W.J.; Liskamp, R.M.; Corstens, F.H.; Boerman, O.C. Effects of linker variation on the in vitro and in vivo characteristics of an 111In-labeled RGD peptide. Nucl. Med. Biol. 2007, 34, 29-35. [CrossRef]

133. Li, Z.-B.; Cai, W.; Cao, Q.; Chen, K.; Wu, Z.; Elhendy, A.; Chen, X. 64Cu-Labeled Tetrameric and Octameric RGD Peptides for Small-Animal PET of Tumor v 3 Integrin Expression. J. Nucl. Med. 2007, 48, 1162-1171. [CrossRef] [PubMed]

134. Chen, X.; Tohme, M.; Park, R.; Hou, Y.; Bading, J.R.; Conti, P.S. Micro-PET Imaging of $\alpha v \beta 3$-Integrin Expression with 18F-Labeled Dimeric RGD Peptide. Mol. Imaging 2004, 3, 96-104. [CrossRef]

135. Shi, J.; Kim, Y.-S.; Zhai, S.; Liu, Z.; Chen, X.; Liu, S. Improving Tumor Uptake and Pharmacokinetics of64Cu-Labeled Cyclic RGD Peptide Dimers with Gly3and PEG4Linkers. Bioconjugate Chem. 2009, 20, 750-759. [CrossRef]

136. Dijkgraaf, I.; Kruijtzer, J.A.W.; Liu, S.; Soede, A.C.; Oyen, W.J.; Corstens, F.H.M.; Liskamp, R.M.J.; Boerman, O.C. Improved targeting of the $\alpha v \beta 3$ integrin by multimerisation of RGD peptides. Eur. J. Nucl. Med. Mol. Imaging 2007, 34, 267-273. [CrossRef] [PubMed]

137. Pirooznia, N.; Abdi, K.; Beiki, D.; Emami, F.; Arab, S.S.; Sabzevari, O.; Pakdin-Parizi, Z.; Geramifar, P. Radiosynthesis, Biological Evaluation, and Preclinical Study of a 68Ga-Labeled Cyclic RGD Peptide as an Early Diagnostic Agent for Overexpressed $\alpha v \beta 3$ Integrin Receptors in Non-Small-Cell Lung Cancer. Contrast Media Mol. Imaging 2020, 2020. [CrossRef]

138. Zhang-Yin, J.; Provost, C.; Cancel-Tassin, G.; Rusu, T.; Penent, M.; Radulescu, C.; Comperat, E.; Cussenot, O.; Montravers, F.; Renard-Penna, R.; et al. A comparative study of peptide-based imaging agents [68Ga]Ga-PSMA-11, [68Ga]Ga-AMBA, [68Ga]Ga-NODAGA-RGD and [68Ga]Ga-DOTA-NT-20.3 in preclinical prostate tumour models. Nucl. Med. Biol. 2020, 84-85, 88-95. [CrossRef]

139. Novy, Z.; Stepankova, J.; Hola, M.; Flasarova, D.; Popper, M.; Petrik, M. Preclinical Evaluation of Radiolabeled Peptides for PET Imaging of Glioblastoma Multiforme. Molecules 2019, 24, 2496. [CrossRef] [PubMed]

140. Isal, S.; Pierson, J.; Imbert, L.; Clement, A.; Collet, C.; Pinel, S.; Veran, N.; Reinhard, A.; Poussier, S.; Gauchotte, G.; et al. PET imaging of 68Ga-NODAGA-RGD, as compared with 18F-fluorodeoxyglucose, in experimental rodent models of engrafted glioblastoma. EJNMMI Res. 2018, 8, 51. [CrossRef] [PubMed]

141. Chen, Z.; Fu, H.; Wu, H.; Huang, J.; Yao, L.; Zhang, X.; Li, Y. Syntheses and Preliminary Evaluation of Dual Target PET Probe [18F]-NOTA-Gly3- E (2PEG4-RGD-WH701) for PET Imaging of Breast Cancer. Anti-Cancer Agents Med. Chem. 2020, 20, $1548-1557$. [CrossRef]

142. Li, L.; Ma, L.; Shang, N.; Liu, Z.; Yu, Q.; Wang, S.; Teng, X.; Zhang, Q.; Hu, X.; Zhao, W.; et al. Pretreatment PET/CT imaging of angiogenesis based on 18F-RGD tracer uptake may predict antiangiogenic response. Eur. J. Nucl. Med. Mol. Imaging 2018, 46, 940-947. [CrossRef]

143. Van Der Gucht, A.; Pomoni, A.; Jreige, M.; Allemann, P.; Prior, J.O. 68Ga-NODAGA-RGDyK PET/CT Imaging in Esophageal Cancer. Clin. Nucl. Med. 2016, 41, e491-e492. [CrossRef] [PubMed]

144. Li, L.; Zhao, W.; Sun, X.; Liu, N.; Zhou, Y.; Luan, X.; Gao, S.; Zhao, S.; Yu, J.; Yuan, S. 18F-RGD PET/CT imaging reveals characteristics of angiogenesis in non-small cell lung cancer. Transl. Lung Cancer Res. 2020, 9, 1324-1332. [CrossRef] [PubMed]

145. Kim, M.; Kim, T.M.; Keam, B.; Kim, Y.J.; Paeng, J.C.; Moon, K.C.; Kim, D.; Heo, D.S. A Phase II Trial of Pazopanib in Patients with Metastatic Alveolar Soft Part Sarcoma. Oncologist 2018, 24, 20-e29. [CrossRef] [PubMed]

146. Zheng, S.; Chen, Z.; Huang, C.; Chen, Y.; Miao, W. [99mTc]3PRGD2 for integrin receptor imaging of esophageal cancer: A comparative study with [18F]FDG PET/CT. Ann. Nucl. Med. 2018, 33, 135-143. [CrossRef] [PubMed]

147. Li, D.; Zhang, J.; Ji, N.; Zhao, X.; Zheng, K.; Qiao, Z.; Li, F.; Lang, L.; Iagaru, A.; Niu, G.; et al. Combined 68Ga-NOTA-PRGD2 and 18F-FDG PET/CT Can Discriminate Uncommon Meningioma Mimicking High-Grade Glioma. Clin. Nucl. Med. 2018, 43, 648-654. [CrossRef]

148. Ikeda, N.; Nakajima, Y.; Tokuhara, T.; Hattori, N.; Sho, M.; Kanehiro, H.; Miyake, M. Clinical significance of aminopeptidase N/CD13 expression in human pancreatic carcinoma. Clin. Cancer Res. 2003, 9, 1503-1508.

149. Pang, L.; Zhang, N.; Xiangwei, M.; Wang, D.; Wang, G.; Meng, X. Serum APN/CD13 as a novel diagnostic and prognostic biomarker of pancreatic cancer. Oncotarget 2016, 7, 77854-77864. [CrossRef]

150. Shimizu, T.; Tani, K.; Hase, K.; Ogawa, H.; Huang, L.; Shinomiya, F.; Sone, S. CD13/aminopeptidase N-induced lymphocyte involvement in inflamed joints of patients with rheumatoid arthritis. Arthritis Rheum. 2002, 46, 2330-2338. [CrossRef]

151. Ma, W.; Kang, F.; Wang, Z.; Yang, W.; Li, G.; Ma, X.; Li, G.; Chen, K.; Zhang, Y.; Wang, J. 99mTc-labeled monomeric and dimeric NGR peptides for SPECT imaging of CD13 receptor in tumor-bearing mice. Amino Acids 2013, 44, 1337-1345. [CrossRef]

152. Persigehl, T.; Ring, J.; Bremer, C.; Heindel, W.; Holtmeier, R.; Stypmann, J.; Claesener, M.; Hermann, S.; Schäfers, M.; Zerbst, C.; et al. Non-invasive monitoring of tumor-vessel infarction by retargeted truncated tissue factor tTF-NGR using multi-modal imaging. Angiogenesis 2013, 17, 235-246. [CrossRef] [PubMed] 
153. Kis, A.; Dénes, N.; Szabó, J.P.; Arató, V.; Jószai, I.; Enyedi, K.N.; Lakatos, S.; Garai, I.; Mező, G.; Kertész, I.; et al. In vivo assessment of aminopeptidase N (APN/CD13) specificity of different 68Ga-labelled NGR derivatives using PET/MRI imaging. Int. J. Pharm. 2020, 589, 119881. [CrossRef] [PubMed]

154. Gao, Y.; Wang, Z.; Ma, X.; Ma, W.; Zhao, M.; Fu, T.; Li, G.; Wang, S.; Wang, Z.; Yang, W.; et al. The uptake exploration of 68Ga-labeled NGR in well-differentiated hepatocellular carcinoma xenografts: Indication for the new clinical translational of a tracer based on NGR. Oncol. Rep. 2017, 38, 2859-2866. [CrossRef] [PubMed]

155. Liu, Y.; Wang, Z.; Li, X.; Kang, F.; Ma, X.; Yang, W.; Ma, W.; Wang, J. A Uniquely Modified DKL-based Peptide Probe for Positron Emission Tomography Imaging. Curr. Pharm. Des. 2019, 25, 96-103. [CrossRef]

156. Gai, Y.; Jiang, Y.; Long, Y.; Sun, L.; Liu, Q.; Qin, C.; Zhang, Y.; Zeng, D.; Lan, X. Evaluation of an Integrin $\alpha v \beta 3$ and Aminopeptidase N Dual-Receptor Targeting Tracer for Breast Cancer Imaging. Mol. Pharm. 2019, 17, 349-358. [CrossRef] [PubMed]

157. Ma, W.; Shao, Y.; Yang, W.; Li, G.; Zhang, Y.; Zhang, M.; Zuo, C.; Chen, K.; Wang, J. Evaluation of 188Re-labeled NGR-VEGI protein for radioimaging and radiotherapy in mice bearing human fibrosarcoma HT-1080 xenografts. Tumor Biol. 2016, 37, 9121-9129. [CrossRef]

158. Zhao, L.; Chen, H.; Guo, Z.; Fu, K.; Yao, L.; Fu, L.; Guo, W.; Wen, X.; Jacobson, O.; Zhang, X.; et al. Targeted Radionuclide Therapy in Patient-Derived Xenografts Using 177Lu-EB-RGD. Mol. Cancer Ther. 2020, 19, 2034-2043. [CrossRef]

159. Chen, H.; Zhao, L.; Fu, K.; Lin, Q.; Wen, X.; Jacobson, O.; Sun, L.; Wu, H.; Zhang, X.; Guo, Z.; et al. Integrin $\alpha$ v $\beta 3-t a r g e t e d$ radionuclide therapy combined with immune checkpoint blockade immunotherapy synergistically enhances anti-tumor efficacy. Theranostics 2019, 9, 7948-7960. [CrossRef] 